\title{
Analysis of sulfate aerosols over Austria: a case study
}

\author{
Camelia Talianu ${ }^{1,2}$ and Petra Seibert ${ }^{1}$ \\ ${ }^{1}$ Institute of Meteorology, University of Natural Resources and Life Sciences, Vienna, Austria \\ ${ }^{2}$ National Institute of R\&D for Optoelectronics, Măgurele, Romania
}

Correspondence: Camelia Talianu (camelia.talianu@boku.ac.at)

Received: 31 October 2018 - Discussion started: 17 December 2018

Revised: 17 April 2019 - Accepted: 23 April 2019 - Published: 13 May 2019

\begin{abstract}
An increase in the sulfate aerosols observed in the period 1-6 April 2014 over Austria is analyzed using in situ measurements at an Austrian air quality background station, lidar measurements at the closest EARLINET stations around Austria, CAMS near-real-time data, and particle dispersion modeling using FLEXPART, a Lagrangian transport model. In situ measurements of $\mathrm{SO}_{2}, \mathrm{PM}_{2.5}, \mathrm{PM}_{10}$, and $\mathrm{O}_{3}$ were performed at the air quality background station Pillersdorf, Austria (EMEP station AT30, 48 $43^{\prime} \mathrm{N}, 15^{\circ} 55^{\prime} \mathrm{E}$ ). A CAMS aerosol mixing ratio analysis for Pillersdorf and the lidar stations Leipzig, Munich, Garmisch, and Bucharest indicates the presence of an event of aerosol transport, with sulfate and dust as principal components. For the sulfate layers identified at Pillersdorf from the CAMS analysis, backwardand forward-trajectory analyses were performed, associating lidar stations with the trajectories. The lidar measurements for the period corresponding to trajectory overpass of associated stations were analyzed, obtaining the aerosol layers, the optical properties, and the aerosol types. The potential sources of transported aerosols were determined for Pillersdorf and the lidar stations using the source-receptor sensitivity computed with FLEXPART, combined with the MACCity source inventory. A comparative analysis for Pillersdorf and the trajectory-associated lidar stations showed consistent aerosol layers, optical properties and types, and potential sources. A complex pattern of contributions to sulfate over Austria was found in this paper. For the lower layers (below $2000 \mathrm{~m}$ ) of sulfate, it was found that central Europe was the main source of sulfate. Medium to smaller contributions come from sources in eastern Europe, northwest Africa, and the eastern US. For the middle-altitude layers (between 2000 and $5000 \mathrm{~m}$ ), sources from central Europe (northern Italy, Serbia, Hungary) contribute with similar emissions. Northwest Africa and the eastern US also have important contribu-
\end{abstract}

tions. For the high-altitude layers (above $5000 \mathrm{~m}$ ), the main contributions come from northwest Africa, but sources from the southern and eastern US also contribute significantly. No contributions from Europe are seen for these layers. The methodology used in this paper can be used as a general tool to correlate measurements at in situ stations and EARLINET lidar stations around these in situ stations.

\section{Introduction}

Sulfate is one of the major aerosol components for particles with a diameter smaller than $2.5 \mu \mathrm{m}\left(\mathrm{PM}_{2.5}\right)$ and for particles with a diameter smaller than $10 \mu \mathrm{m}\left(\mathrm{PM}_{10}\right)$. Other components of the particulate matter (PM) are organic carbon (OC), elemental carbon (EC), nitrate, ammonia, minerals, and sea salt. Sulfate normally accounts for about $10 \%$ to $30 \%$ of PM mass concentration (Stocker et al., 2013); worldwide in situ observations of refractory $\mathrm{PM}_{1}$ chemical composition have shown that the sulfate contribution may reach more than $50 \%$ of aerosol mass, depending on the location (Zhang et al., 2007). More details about the mass concentration of these aerosol components from various rural and urban sites in Europe are given in the IPCC AR5 report (Stocker et al., 2013). The anthropogenic sulfate is produced mainly by oxidation of sulfur dioxide $\left(\mathrm{SO}_{2}\right)$, or produced by aqueous phase reactions, where $\mathrm{O}_{3}$ and hydrogen peroxide act as important oxidants (Seinfeld and Pandis, 2006), or by adsorption of $\mathrm{SO}_{2}$ on solid particles and subsequent reaction with adsorbed oxygen; the exact mechanism depends on several atmospheric factors (solar radiation, presence of catalysts, $\mathrm{NO}_{x}$, temperature, relative humidity, etc.). The adsorption is an important mechanism of sulfate production in the urban atmosphere. Soot (elemental carbon) parti- 
cles and semiconductor metal oxide particulates from mineral dust (e.g., $\mathrm{Fe}_{2} \mathrm{O}_{3}, \mathrm{TiO}_{2}$ ) are potential surfaces for this process (Dupart et al., 2012). The primary precursor for sulfate in the troposphere is $\mathrm{SO}_{2}$ emitted (Solomon et al., 2007) from

- anthropogenic sources: a major contribution from combustion of fossil fuel (about $72 \%$ ) and a small contribution from biomass burning (about $2 \%$ );

- natural sources: from dimethyl sulfide (DMS) emissions by marine phytoplankton (about $19 \%$ ) and from volcano eruptions (about $7 \%$ ).

A recent review of $\mathrm{SO}_{2}$ sources worldwide can be found in Yang et al. (2017).

In addition to chemical processes, $\mathrm{SO}_{2}$ is removed efficiently by dry deposition, while sulfate aerosol is removed from the atmosphere by wet deposition (Seinfeld and Pandis, 2006). Tropospheric sulfate, mostly in the accumulation mode, has a lifetime estimated at 1 week (AeroCom, 2018). The optical, physical, and chemical properties of the sulfate are well defined (Solomon et al., 2007). Sulfate particles have a cooling effect by light scattering (AeroCom, 2018; Stocker et al., 2013), they are very hygroscopic and therefore represent active cloud condensation nuclei, and they enhance absorption when deposited as a coating on elemental carbon. The direct radiative effects are strongly correlated to the emission sources, while the indirect effects are correlated to both emission sources and cloud cover (Déandreis et al., 2012; Yang et al., 2017). As a main component in the aerosols, sulfate can have an important contribution to the aerosol optical depth (AOD).

The purpose of this study is

- to assess the relation between the excess with respect to monthly averaged values observed in the in situ measurements of $\mathrm{SO}_{2}, \mathrm{O}_{3}, \mathrm{PM}_{2.5}$, and $\mathrm{PM}_{10}$ at the Austrian air quality background station Pillersdorf at the beginning of April 2014 with aerosol layers observed in lidar measurements at the closest EARLINET stations around Austria and with tropospheric sulfate aerosols as found in Copernicus Atmosphere Monitoring Service (CAMS) products (CAMS, 2018).

- to estimate the potential sources of sulfate aerosols.

The study is based on the synergy of the remote-sensing instruments from the European Aerosol Research Lidar Network (EARLINET) (Boesenberg et al., 2003); the ceilometer network of the German Meteorological Service (DWD) and in situ monitors, combined with CAMS products and the NATALI aerosol-typing model (Nicolae et al., 2018); and atmospheric transport modeling. The ground-based remotesensing instruments and the CAMS products (assimilating satellite-based remote-sensing data) are used to determine the properties of long-range-transported aerosols and their vertical distribution. In situ measurements of PM and trace gases provide local concentrations at the surface and at specific heights in the troposphere. Details about data collection are given in Sect. 2.1.

The back-trajectory analysis relates the aerosol mass loading changes at a receptor location to spatially fixed sources, identifying the sources by a source-receptor matrix calculation (Seibert and Frank, 2004; Eckhardt et al., 2017). In this paper, the analysis of the trajectories has been performed with FLEXTRA (Stohl et al., 1995; FLEXTRA, 2018), while the estimation of the potential areas of aerosols' sources has been performed using the Lagrangian transport model FLEXPART (Stohl et al., 2005, Andreas Stohl et al., unpublished data, 2010). A detailed description of the processing of the collected data and the subsequent analysis is given in Sect. 2.3, while the results and the discussion are presented in Sect. 3.

The synergy of the in situ remote-sensing data and models was used in more atmospheric studies related to longrange-transported aerosols and estimation of their potential sources; see for example Papayannis et al. (2014) for dust, Nicolae et al. (2013) and Ansmann et al. (2018) for fires, Eckhardt et al. (2008) and Cazacu et al. (2012) for volcanic ash, and Sauvage et al. (2017), Chalbot et al. (2013), and Kaskaoutis et al. (2012) for anthropogenic aerosols. However, to the best of our knowledge, there have been no studies combining CAMS-based aerosol data with remote-sensing in situ measurements and transport models. The assimilation of ground-based remote-sensing measurements in CAMS is a long-term goal.

\section{Methodology}

The optical properties of the aerosol considered in this analysis are backscatter coefficients, extinction coefficients, volume depolarization ratio, particle depolarization ratio (PDepR), lidar ratio (LR), and Ångström exponent (AE).

In this paper, all times are given as UTC times, in the format HH:mm, HH being the hour and $\mathrm{mm}$ the minutes. The altitudes are given as ground-level altitudes (a.g.l.).

Whenever referring to measurements, the geographical name is used as an indicator for the station location (e.g., Pillersdorf means Pillersdorf site; Leipzig means Leipzig lidar station). In the plots, the stations are represented as Pillersdorf (red circle), Leipzig (green circle), Munich (magenta triangle), Garmisch (blue rhombus), and Bucharest (black square).

\subsection{Data collection}

The in situ measurement of $\mathrm{SO}_{2}, \mathrm{PM}_{2.5}, \mathrm{PM}_{10}$, and $\mathrm{O}_{3}$ were performed at the air quality background station Pillersdorf, Austria (EMEP station AT30, $48^{\circ} 43^{\prime} \mathrm{N}, 15^{\circ} 55^{\prime} \mathrm{E}$ ) (Umweltbundesamt Austria, 2014). Pillersdorf (315 m) is located in 
hilly terrain in the northeastern part of Austria, around $60 \mathrm{~km}$ north from Vienna. The station is a part of the national background monitoring network and an EMEP background monitoring station. The surroundings are mostly forests and agricultural areas far from strong anthropogenic sources. Austria belongs to the midlatitude climate belt, in the transition between maritime and continental climate, and the weather is dominated mostly by traveling highs and lows. The station provides

- daily mean concentration and the maximum half-hour mean value per day for $\mathrm{SO}_{2}$,

- daily mean concentration for $\mathrm{PM}_{2.5}$ and $\mathrm{PM}_{10}$,

- maximum value per day of hourly mean concentrations and maximum value per day of $8 \mathrm{~h}$ mean concentrations for $\mathrm{O}_{3}$.

The $\mathrm{SO}_{2}$ measurements are performed with a $\mathrm{SO}_{2}$ analyzer, with a detection limit of $0.05 \mathrm{ppb}$, and a range up to $100 \mathrm{ppm}$. The $\mathrm{PM}_{2.5}$ and $\mathrm{PM}_{10}$ measurements are performed with an optical particle counter with a precision of $0.1 \mu \mathrm{g} \mathrm{m}^{-3}$. The $\mathrm{O}_{3}$ measurements are performed with an ozone analyzer, with a detection limit of $0.4 \mathrm{ppb}$ and a range of 0.05 to 200 ppm.

The EARLINET lidar stations (Wandinger et al., 2016) used for this study are Garmisch-Partenkirchen $\left(47.47^{\circ} \mathrm{N}\right.$, $\left.11.06^{\circ} \mathrm{E}\right)$, Leipzig $\left(51.35^{\circ} \mathrm{N}, 12.43^{\circ} \mathrm{E}\right)$ (both stations located in Germany), and Bucharest $\left(44.35^{\circ} \mathrm{N}, 26.03^{\circ} \mathrm{E}\right.$, Romania). The two DWD ceilometer stations used are located in Munich $\left(48.20^{\circ} \mathrm{N}, 11.45^{\circ} \mathrm{E}\right)$ and Schneefernerhaus $\left(47.42^{\circ} \mathrm{N}, 10.98^{\circ} \mathrm{E}\right)$. The following remote-sensing devices are deployed:

- high-spectral-resolution lidar (HSRL) (Wandinger et al., 2016), located at Garmisch-Partenkirchen, Germany;

- portable Raman multispectral lidar system Polly XT (Engelmann et al., 2016), having eight channels including one water vapor channel and two depolarization channels, located at Leipzig, Germany;

- Raman multispectral lidar system (RALI) (Belegante et al., 2014), having seven channels including one water vapor channel and one depolarization channel, located at Bucharest, Romania;

- ceilometers (Wiegner and Geiß, 2012) at Munich and Schneefernerhaus, Germany.

The measurements were performed at the following wavelengths: 355, 532, and $1064 \mathrm{~nm}$ for the elastic channels; 387 and $607 \mathrm{~nm}$ for the Raman channels; and $532 \mathrm{~nm}$ for the depolarization channel. For HSRL, the $313 \mathrm{~nm}$ channel was used. For ceilometers, the $1064 \mathrm{~nm}$ channel was used.
The lidar and the ceilometer measurements provide the vertical distributions of aerosols, retrieved from the range corrected signal (RCS, the preprocessed lidar/ceilometer signal corrected with squared range), and the vertical distributions of aerosol polarization, if the instrument is equipped with a polarization channel.

For the remote-sensing sites Leipzig, Munich, and Bucharest, the column-integrated AOD measurements for various wavelengths were taken from the AERONET sunsky photometer measurements, the AERONET instruments being collocated with the lidar stations.

In this paper, products from CAMS, the Copernicus Atmosphere Monitoring Service (CAMS, 2018) of the European Earth Observation program Copernicus were also used; it provides global reanalysis datasets for the period 2003-2012, and global near-real-time (NRT) datasets (Dee et al., 2011) for 2013 to present. These datasets were produced (Benedetti et al., 2009) using 4D-Var data assimilation in CY42R1 of ECMWF's Integrated Forecast System (IFS), with 60 hybrid sigma-pressure (model) levels in the vertical, with the top level at $0.1 \mathrm{hPa}$. Atmospheric data are available on these levels and they are also interpolated to 25 pressure, 10 potential temperature, and one potential vorticity level(s). "Surface or single level" data are also available.

For this analysis, the CAMS products for "model levels" and "surface level" from the NRT "Atmospheric Composition" dataset were selected for the times 00:00, 06:00, 12:00, and 18:00 for the analysis data and a step of $3 \mathrm{~h}$ for forecast data. The mixing ratios of dust, hydrophilic and hydrophobic black carbon, hydrophilic and hydrophobic organic matter, and sulfate were retrieved from the lowest 31 model levels, which cover the tropospheric altitudes; temperature and specific humidity were also retrieved for the same model levels. The logarithm of surface pressure was retrieved from the lowest model level, while the geopotential and aerosol optical depth (AOD) at $550 \mathrm{~nm}$ for total aerosol, black carbon, organic matter, dust, and sulfate were retrieved from the surface level.

\subsection{Aerosol and atmospheric transport modeling}

In this paper, the models FLEXPART and FLEXTRA were used for atmospheric transport modeling.

FLEXPART (FLEXible PARTicle dispersion model) is a Lagrangian particle dispersion model designed for calculating the long-range and mesoscale transport, diffusion, dry and wet deposition, and radioactive decay of air pollutants from point, line area, and volume sources. FLEXPART can be run in forward mode, simulating the transport and dispersion of emissions from given sources towards receptor points or producing gridded output concentration and deposition, or in backward mode from given receptors to produce sourcereceptor relationships with respect to a point source or gridded sources (Seibert and Frank, 2004). The model ingests ECMWF 3-D meteorological fields and solves the equations 
for transport, turbulent diffusions, and other relevant processes in a Lagrangian framework (Stohl et al., 1998; Pisso et al., 2019). The sensitivity of a receptor concentration to potential sources is obtained directly as the model output in the case of a backward run (Seibert and Frank, 2004; Eckhardt et al., 2017).

FLEXTRA is a kinematic trajectory model. It simulates only the transport of air parcels by mean winds, ignoring turbulence and convection, and does not provide concentrations, deposition, etc.

For both models the ECMWF (European Centre for Medium-Range Weather Forecasts) ERA-Interim meteorological fields with a horizontal resolution of $0.5^{\circ} \times 0.5^{\circ}$, the lowest 61 vertical levels (corresponding to pressure levels from the surface to $250 \mathrm{hPa}$ ) out of the 137 vertical levels, and a temporal resolution of $3 \mathrm{~h}$ were used. A sub-domain covering a part of the Northern Hemisphere $\left(175^{\circ} \mathrm{W}-60^{\circ} \mathrm{E}\right.$, $0-90^{\circ} \mathrm{N}$ ), including Europe, a part of the Atlantic Ocean, North America, and a part of Africa was extracted as the "mother" domain.

For the determination of the aerosol optical properties for sites without lidar measurements, where the aerosol composition is determined from CAMS products, the aerosol model from Nicolae et al. (2018) was used, called in the following the NATALI aerosol model. Six classes of typical aerosol (called "pure aerosol" in the reference) were considered in this model: continental, continental polluted, dust, marine, smoke, and volcanic. In the model, the optical properties are computed for typical aerosols and for mixtures of two or three typical aerosols at fixed wavelengths 350,550 , and $1000 \mathrm{~nm}$ with the T-matrix method using light scattering on nonspherical particles (Mishchenko et al., 1996) for a lognormal distribution of homogeneous particles. The microphysical parameters (effective radius, standard deviation, and complex refractive indices) of the components, needed as input in the model, were taken from the GADS (Global Aerosol Data Set) database (Koepke et al., 1997).

For the comparison with optical properties obtained from lidar measurements, the optical properties computed in the model are rescaled to the lidar wavelengths $(355,532$, and $1064 \mathrm{~nm}$ ) using an AE equal to 1, as the values of model and lidar wavelengths are very close.

\subsection{Data processing and analysis}

\subsubsection{Lidar and ceilometer data processing}

The vertical profiles of the backscatter coefficients were determined using the Fernald-Klett method (Fernald, 1984; Klett, 1981) for remote-sensing instruments with only elastic channels. For instruments with elastic and Raman channels, the backscatter and the extinction coefficients were determined using the combined method (Ansmann et al., 1992). The PDepR was computed using the volume depolarization ratio and the backscatter coefficients (Freudenthaler, 2016).
The AE is computed from the extinction coefficients for the wavelengths 532 and $355 \mathrm{~nm}$.

The LR was computed as the ratio of the extinction coefficient to backscatter coefficient. For ceilometers, lidars with only elastic channels, and lidar measurements during the day (when only backscatter coefficients can be retrieved), the value of the LR was taken from the NATALI aerosol model, which gives an estimate of the LR for 14 aerosol types. The values for $532 \mathrm{~nm}$ used in this paper are $23 \pm 10 \mathrm{sr}$ for marine, $40 \pm 8 \mathrm{sr}$ for dust, $68 \pm 6 \mathrm{sr}$ for continental, $52 \pm 2 \mathrm{sr}$ for continental polluted, $53 \pm 5 \mathrm{sr}$ for polluted dust, $64 \pm 8 \mathrm{sr}$ for smoke, and $46 \pm 10 \mathrm{sr}$ for mixed dust.

The aerosol layers are identified from the lidar measurements with the gradient method, applied to the RCS profiles (Belegante et al., 2014; Nicolae et al., 2018). The gradient method is based on the identification of the peaks and valleys from the first derivative applied to the vertical profiles. If two consecutive layers are very close (less than $100 \mathrm{~m}$ ), these layers are merged into one layer. Also, if the signal-tonoise ratio in the layer is lower than a threshold (here set to 5), the layer is discarded.

The aerosol type is determined from the lidar measurements using the NATALI typing algorithm, described in Nicolae et al. (2018).

\subsubsection{CAMS product processing}

The values of the CAMS products (mixing ratios, temperature, specific humidity, etc.) for a given location were computed by interpolating the gridded CAMS values, using the inverse weighting distance interpolation.

The air density and the altitude specific to the model levels were computed according to CY42R1 from IFS documentation (Benedetti et al., 2009).

\subsubsection{Data analysis}

The concentrations of $\mathrm{SO}_{2}, \mathrm{PM}_{2.5}, \mathrm{PM}_{10}$, and $\mathrm{O}_{3}$ measured in situ at the air quality background station Pillersdorf were analyzed for sliding periods of 1 month to identify excesses with respect to the measured average values. If a significant excess is identified (values exceed the averaged values by $50 \%$ for $30 \mathrm{~d}$ ), the corresponding period is analyzed in detail, also using CAMS products at the in situ station and measurements and CAMS products at the closest lidar stations around the in situ station. For spring 2014, a period with a significant excess was identified in the time interval 15 March-14 April, which is presented in this paper.

The CAMS products are retrieved for the in situ site. The time series of mixing ratios of sulfate, dust, organic matter, and total aerosols are then analyzed for the same period as the in situ data. If one of the aerosol components has no significant contribution to the aerosol concentration, this component can be neglected in the subsequent analysis of the 
aerosol. The time series are also retrieved for the lidar stations around the in situ site.

To assess if the excess is caused by a local event or long- or medium-range-transported aerosol is involved, a qualitative analysis of the in situ concentration measurements and the time series of mixing ratios at the in situ station and at the lidar stations around the in situ station is performed. If the event is present only at the in situ station, we can assume that it is a local event. If the event is seen at some of the lidar stations around the in situ site, the event has contributions from an aerosol transport event.

The layers for the event at the in situ site are then determined by applying the same gradient method as for lidar data processing, but applied to the altitude profiles of aerosol concentrations. The concentrations are computed by multiplying the CAMS mixing ratios and the air density.

A statistical analysis of trajectories is then performed for each layer identified at the in situ site. Three-dimensional kinematic hourly trajectories are computed with the FLEXTRA model, run in backward mode for a transport time of 10-20 d (typical for long-range transport) and in forward mode for a few days for several receptor altitudes between 1500 and $7000 \mathrm{~m}$. Due to the turbulence in the planetary boundary layer, trajectories below $1500 \mathrm{~m}$ are usually not included in the analysis, as mostly local trajectories. During the period under investigation, with low wind speeds and mostly clear skies, the boundary-layer height varied at Pillersdorf from less than $100 \mathrm{~m}$ at night to about $1500 \mathrm{~m}$ in the afternoon.

A trajectory is associated with a lidar station if the projection of the trajectory on the Earth's surface intersects a $0.5^{\circ} \times 0.5^{\circ}$ cell centered on the lidar station location. The altitude of the trajectory and the time the trajectory overpasses the lidar cell are the altitude and time of the FLEXTRA trajectory at the corresponding location.

If a trajectory overpasses a lidar station, the lidar measurements for the overpass time are analyzed. The aerosol layers are identified with the same method (Belegante et al., 2014) as for an in situ station, applied to the RCS profiles. The optical properties are computed for each identified aerosol layer, as described in Sect. 2.3. The type of the aerosol is determined from the optical properties using the NATALI typing algorithm. The aerosol concentrations are also computed for each layer, using the method described in Mamouri and Ansmann (2017). For each layer, the sulfate fraction (SF) is computed as the ratio of sulfate concentration to total aerosol concentration.

The layers determined from lidar measurements are then compared with the altitude of the trajectories overpassing the lidar station. If the altitude matches a layer within a reasonable distance, the trajectory is associated with the layer. The matching distance is defined as $2 \sigma_{\text {lidar }}$, where $\sigma_{\text {lidar }}$ is the effective spatial resolution of the lidar, typically of the order of $\sim 60 \mathrm{~m}$.
The source-receptor sensitivity (SRS) is then computed for each layer identified in the sulfate profile at the in situ station using FLEXPART with sulfate as a passive tracer. The receptor is set to the location of the in situ station, at the altitude determined for that layer and the corresponding event time interval. Sources are considered to be situated between 0 and $100 \mathrm{~m}$. Wet and dry deposition are taken into account in the computation. Combining the source-receptor sensitivity with emission inventories, the relative distributions of $\mathrm{SO}_{2}$ sources for the corresponding sulfate layer are computed. In this study, the MACCity anthropogenic $\mathrm{SO}_{2}$ emission inventories from the Emissions of atmospheric Compounds \& Compilation of Ancillary Data (ECCAD) emission database (Darras et al., 2018) were used.

A cross-check of sulfate concentrations from lidar measurements, CAMS sulfate products, and FLEXPART is carried out for the layers at the lidar stations associated with the layers at the in situ station. One expects the values from the three methods to be in agreement.

The optical properties of the aerosol from each layer at the in situ station are then computed according to Sect. 2.2 and compared with the optical properties of the aerosol from the layers at the lidar stations associated with the layers at the in situ station. The optical properties determined at both sites have to be compatible, up to the changes due to the transport from one site to the other. The compatibility is also crosschecked for the type of aerosols at both stations, where the type is determined using the NATALI aerosol model at the in situ site and the NATALI typing algorithm at the lidar station.

\section{Results and discussion}

\subsection{Results}

The in situ measurements of $\mathrm{SO}_{2}, \mathrm{O}_{3}, \mathrm{PM}_{2.5}$, and $\mathrm{PM}_{10}$ concentrations recorded at Pillersdorf for the period 15 March14 April 2014 (Umweltbundesamt Austria, 2014) are shown in Fig. 1, together with the averaged values for this period (dotted line). An excess with respect to the averaged values is observed for all measurements in the period 1-6 April: $66 \%$ for $\mathrm{SO}_{2}, 11 \%$ for $\mathrm{O}_{3}$, and $90 \%$ for $\mathrm{PM}_{2.5}$ and $\mathrm{PM}_{10}$. If the excess period is excluded from the calculation of the average values, the excess increases to $100 \%$ for $\mathrm{SO}_{2}, 14 \%$ for $\mathrm{O}_{3}$, $153 \%$ for $\mathrm{PM}_{2.5}$, and $143 \%$ for $\mathrm{PM}_{10}$.

The time series of aerosol mixing ratios from CAMS nearreal-time data for Pillersdorf are shown for the same period in Fig. 2 for "total aerosols" (sum of all species defined in CAMS data), for sulfate, and for dust. One observes a sulfate increase with a peak on 2 April, and a second, less pronounced peak on 4 April. The aerosol mixture is dominated by dust and sulfate, as can be seen by qualitatively comparing the total, sulfate, and dust distributions.

Similar distributions, also retrieved from CAMS near-realtime data, are observed for the lidar stations around Pillers- 


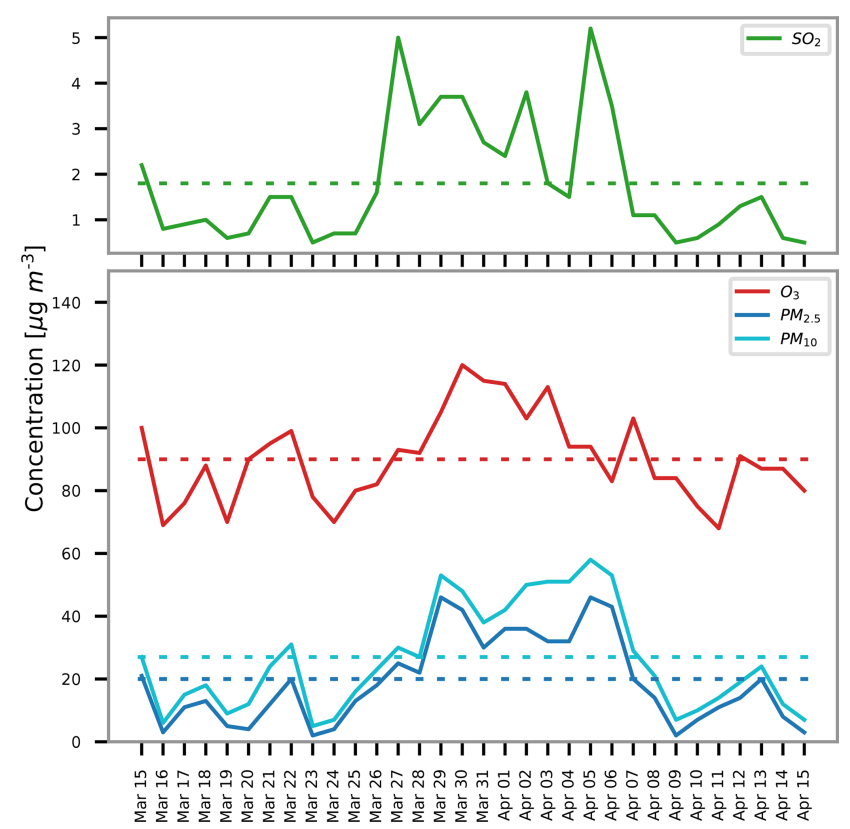

Figure 1. In situ $\mathrm{SO}_{2}, \mathrm{O}_{3}, \mathrm{PM}_{2.5}$, and $\mathrm{PM}_{10}$ concentrations measured at Pillersdorf, Austria (EMEP station AT30, $48^{\circ} 43^{\prime} \mathrm{N}$, $\left.15^{\circ} 55^{\prime} \mathrm{E}\right)$. The dotted lines represent the averaged values for the plotted period.

dorf, as shown in Fig. 3 for Munich, Leipzig, and Bucharest. From these distributions, one can infer the presence of an event of sulfate transport over Europe.

The vertical profiles of sulfate, dust, and total aerosol concentrations are shown in Fig. 4 for Pillersdorf, 2 April. The sulfate layers, identified with the gradient method, are shown as the gray area in the same figure.

For 2 April, from 00:00 to 12:00, sulfate layers mixed with dust are well defined between 2 and $3 \mathrm{~km}$ and between 4 and $6 \mathrm{~km}$. During the day, the layers descend slowly and disperse, such that they mix with dust and the aerosols from the planetary boundary layer. This can also be seen from the concentration profile of total aerosol, which also shows a similar structure, indicating a common transport path of sulfate and dust as polluted dust nearby Pillersdorf. The evolution of the sulfate and dust layers during the day is correlated with the increase in $\mathrm{SO}_{2}$ and $\mathrm{PM}_{2.5}$ concentrations measured in situ, while the evolution of the dust layers is correlated with the increase in the $\mathrm{PM}_{10}$ concentration.

For the layers identified above, the back trajectories of the aerosols were computed with FLEXTRA, starting from Pillersdorf at the time corresponding to the aerosol profiles for a backward period of $12 \mathrm{~d}$. As mentioned before, trajectories below $1500 \mathrm{~m}$ are not computed, due to turbulence in the planetary boundary layer.

For 2 April, they are shown in Fig. 5 for 00:00, 06:00, 12:00, and 18:00. From the trajectory analysis, the time, and the altitude of the trajectories passing over the lidar stations

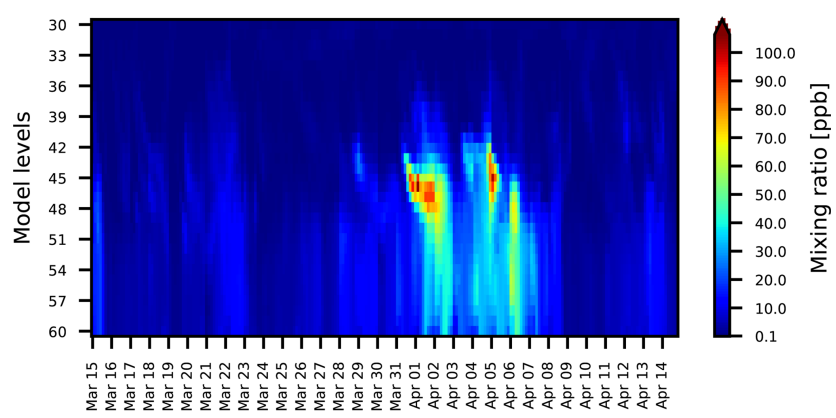

(a) Aerosol

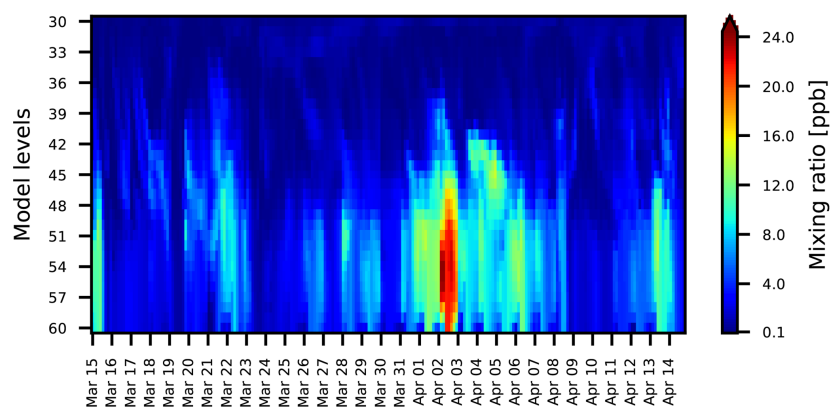

(b) Sulfate

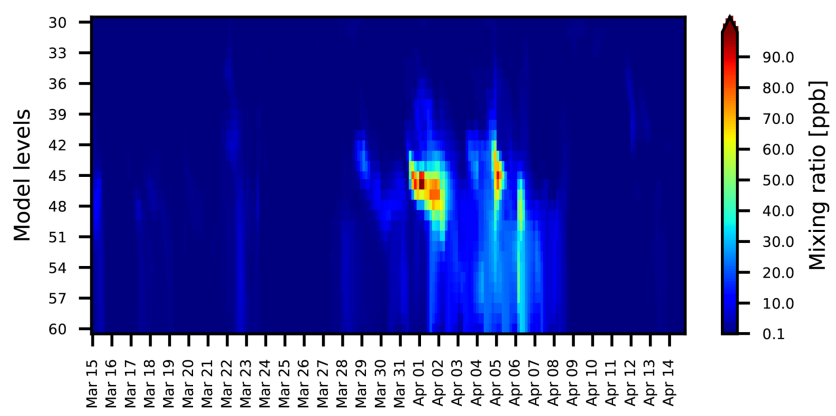

(c) Dust

Figure 2. Time series of CAMS mixing ratios for total aerosol (a), sulfate (b), and dust (c), Pillersdorf, 15 March-14 April 2014.

were determined. The station, the time and the altitude are shown in the lower plots of each panel.

The aerosol layers identified at Pillersdorf were transported further. Some of the layers pass over the lidar station from Bucharest. Their trajectories were analyzed running FLEXTRA in forward mode for $3 \mathrm{~d}$, starting from Pillersdorf. Figure 6 shows the forward trajectories for 2 April, 06:00, which pass over the Bucharest lidar station on 3 April.

The lidar measurements for the stations overpassed by the trajectories determined from the backward and forward analyses are presented as range-corrected signal time series (RCS) in Figs. 7 and 8 and for the event on 2 April in Pillersdorf.

Aerosol layers, their optical properties, and the concentration were determined from the lidar measurements following 


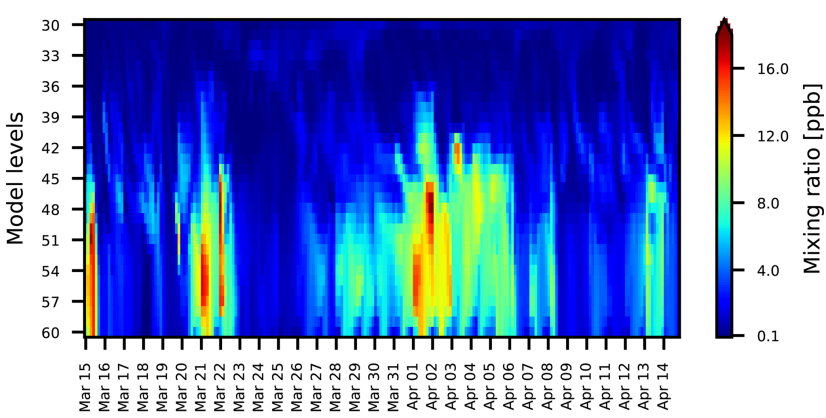

(a) Munich

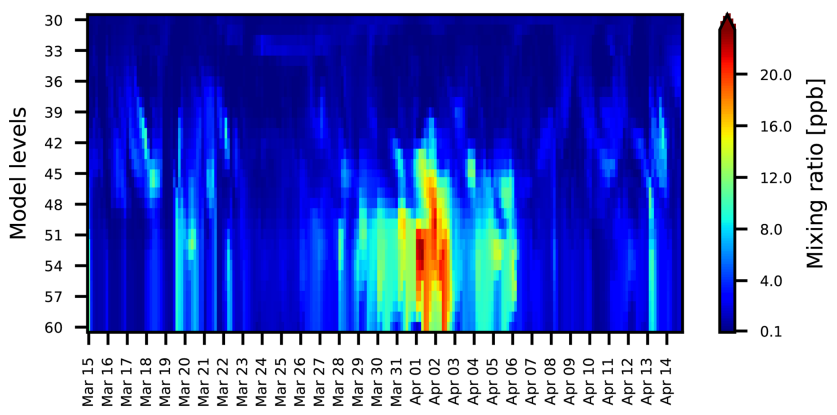

(b) Leipzig

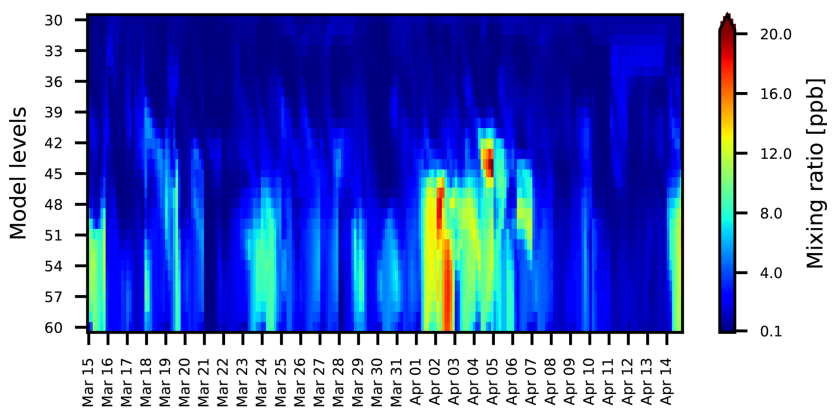

(c) Bucharest

Figure 3. Time series of CAMS mixing ratios for sulfate for $\mathrm{Mu}-$ nich (a), Leipzig (b), and Bucharest (c), 15 March-14 April 2014.

the methodology described in Sect. 2. The layers identified are marked on the corresponding RCS plot.

The association of the layers identified from lidar measurements with the altitude of the backward or forward trajectories over the stations corresponding to the layers identified in Pillersdorf was performed for all eight concentration profiles measured (see Fig. 4 for 2 April and Fig. 13 for 4 April). The association for trajectories from 2 April at 06:00 is presented in Table 1. The trajectory altitude (Traj. alt.) in the table represents the altitude of the trajectory when overpassing the lidar station. The corresponding layers are also marked in the RCS plots (red box).

The source-receptor sensitivity was computed for each layer identified in the sulfate profiles at Pillersdorf; the column-integrated source-receptor sensitivity was also com-

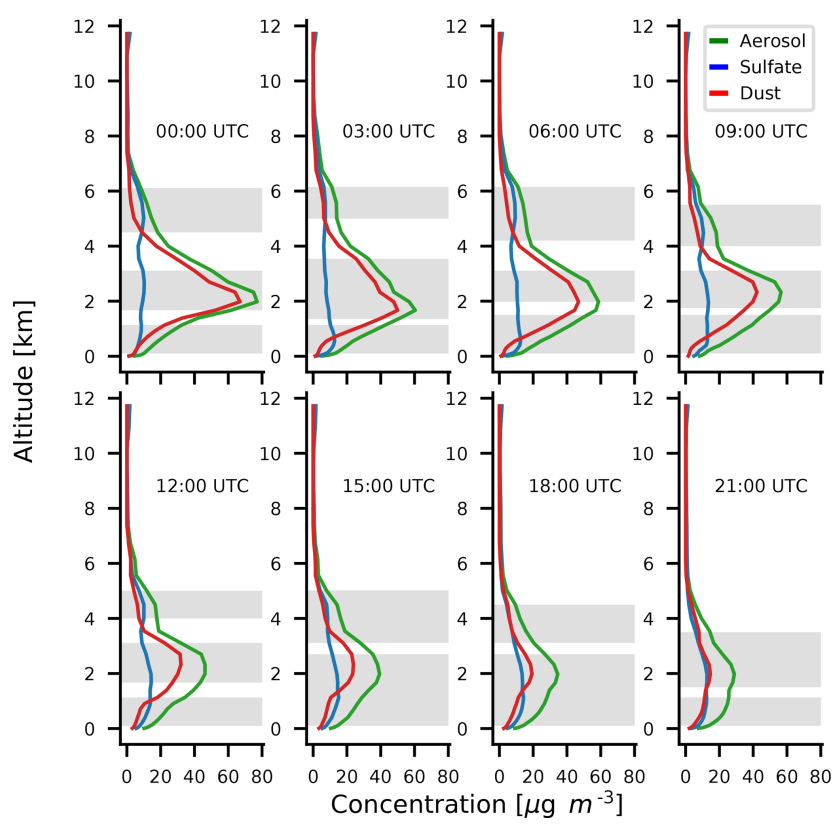

Figure 4. CAMS total aerosol, sulfate, and dust profiles for 2 April 2014, Pillersdorf. The gray area represents the identified sulfate layers. Altitudes are given in kilometers above ground level. Local time is UTC +2 .

Table 1. Association of layers from lidar measurements with layers and trajectories computed for Pillersdorf, 02 April 2014, 06:00.

\begin{tabular}{cc}
\hline \multirow{2}{*}{ Pillersdorf } & \multicolumn{2}{c}{ Lidar station, time } \\
\cline { 2 - 2 } & Traj. alt. $\quad$ Lidar layer \\
\hline \multirow{2}{*}{ L1: 0.55-1.50 km } & Leipzig, $31 \mathrm{Mar}, 18: 00$ \\
& $2.66 \mathrm{~km} \quad 2.70-3.75 \mathrm{~km}$ \\
\hline \multirow{2}{*}{ 22: 1.98-3.11 km } & Leipzig, $31 \mathrm{Mar}, 23: 00$ \\
& $3.75 \mathrm{~km} \quad 3.85-4.20 \mathrm{~km}$ \\
\hline & Munich, $1 \mathrm{Apr}, 05: 00$ \\
& $4.20 \mathrm{~km} \quad 3.54-4.43 \mathrm{~km}$ \\
\cline { 2 - 2 } L3: 4.20-6.15 km & Garmisch, 1 Apr, $14: 00$ \\
& $4.84 \mathrm{~km} \quad 4.91-5.81 \mathrm{~km}$ \\
\cline { 2 - 2 } & Bucharest, $3 \mathrm{Apr}, 13: 00$ \\
& $3.90 \mathrm{~km} \quad 2.70-4.05 \mathrm{~km}$ \\
\hline
\end{tabular}

puted. Figure 9 shows the corresponding distributions for the layers L1, L2, and L3 and total column from 2 April, 06:00.

For each layer, the relative distribution of the $\mathrm{SO}_{2}$ sources was computed from the source-receptor sensitivity and the source inventory MACCity. Figure 10a shows the distribution for layer L1 at Pillersdorf, 2 April, 06:00, while Fig. 10b shows the distribution for the corresponding layer at Leipzig, $31 \mathrm{March}, 18: 00$. To evaluate the local distribution of sources near Pillersdorf, a zoomed view of the $\mathrm{SO}_{2}$ relative distribution is shown in Fig. 10c for the sub-domain covering a part 


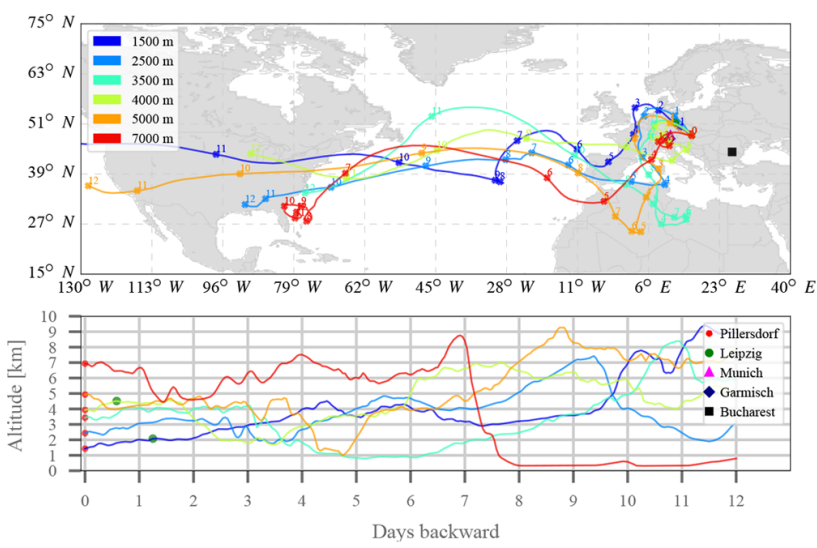

(a) 00:00

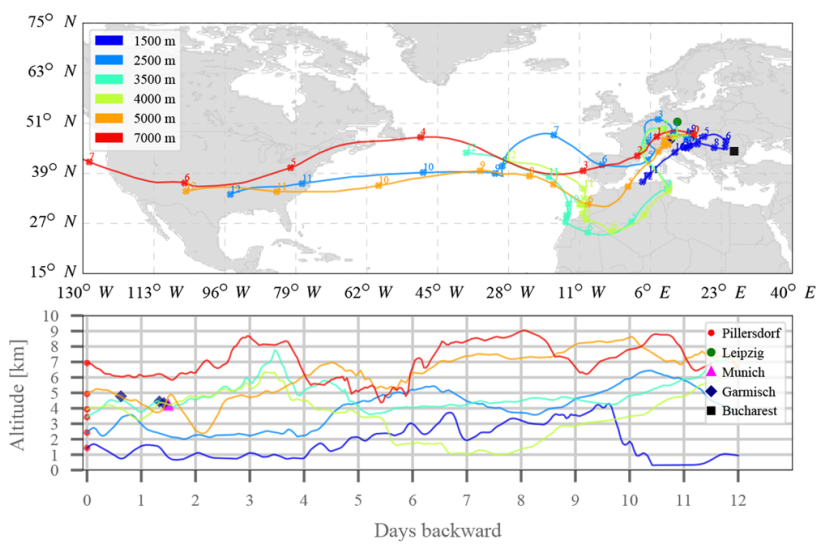

(c) $12: 00$

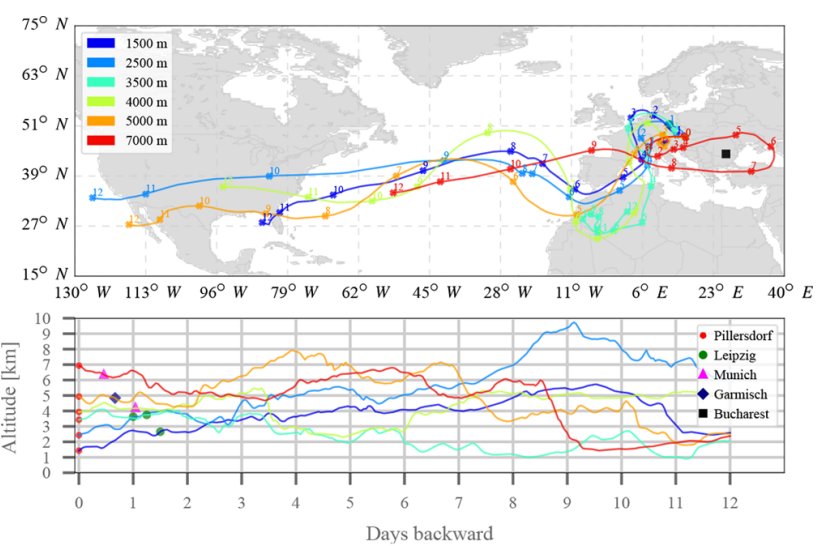

(b) 06:00

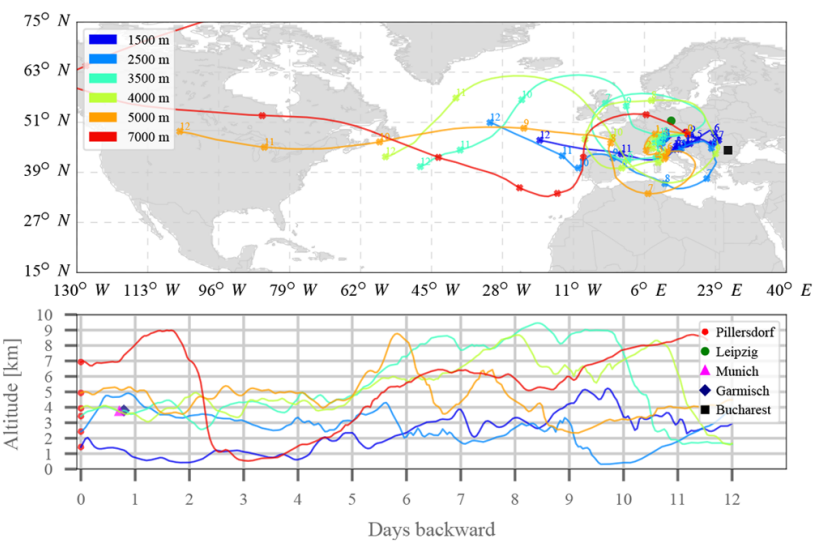

(d) $18: 00$

Figure 5. Pattern of back trajectories (upper plot of each panel) and their altitude profile, including overpassed lidar stations (lower plot of each panel) for Pillersdorf, 2 April 2014 at 00:00 (a), 06:00 (b), 12:00 (c), and 18:00 (d).

of the Europe, centered in Austria $\left(10^{\circ} \mathrm{W}-40^{\circ} \mathrm{E}, 35-60^{\circ} \mathrm{N}\right)$. Similar distributions are shown for layer L2 in Pillersdorf in Fig. 11a, with a corresponding layer in Leipzig (31 March, 23:00), shown in Fig. 11b, and the zoomed view for Pillersdorf in Fig. 11c. For layer L3 at Pillersdorf, the distribution is shown in Fig. 12a, with associated layers in Munich (1 April, 05:00), Garmisch (1 April, 14:00 - not shown as very close to Munich), and Bucharest (3 April, 13:00) shown in Fig. 12b and c, and a zoomed view for Pillersdorf in Fig. 12d.

For the lidar stations, a comparison of concentrations computed from the lidar measurements with the sulfate concentrations computed from CAMS values for the lidar station location and the concentrations computed from the modeled SRS are given in Table 2.

The optical properties, the sulfate fraction, and the aerosol types for the aerosol layers identified for Pillersdorf, 2 April, 06:00 and the associated layers at the lidar stations are given in Table 3. For Leipzig and Bucharest, the optical properties are computed from the lidar measurements; for Pillersdorf, Garmisch, and Munich they are computed using the NATALI model.
Table 2. Comparison of sulfate concentration computed from lidar measurements, CAMS products, and FLEXPART for layers at lidar stations associated with layers from Pillersdorf, 2 April 2014, 06:00.

\begin{tabular}{lccc}
\hline Layer & $\begin{array}{r}C_{\text {lidar }} \\
\left(\mu \mathrm{g} \mathrm{m}^{-3}\right)\end{array}$ & $\begin{array}{r}C_{\text {cams }} \\
\left(\mu \mathrm{g} \mathrm{m}^{-3}\right)\end{array}$ & $\begin{array}{r}C_{\text {flexpart }} \\
\left(\mu \mathrm{g} \mathrm{m}^{-3}\right)\end{array}$ \\
\hline $\begin{array}{l}\text { Leipzig, 31 Mar, 18:00 } \\
\text { 2.70-3.75 km }\end{array}$ & 14.61 & 12.52 & 12.94 \\
\hline $\begin{array}{l}\text { Leipzig, 31 Mar, 23:00 } \\
\text { 3.85-4.20 km }\end{array}$ & 15.96 & 13.48 & 13.42 \\
\hline $\begin{array}{l}\text { Bucharest, 3 Apr, 13:00 } \\
\text { 2.70-4.05 km }\end{array}$ & 15.24 & 11.95 & 13.26 \\
\hline $\begin{array}{l}\text { Munich, 1 Apr, 05:00 } \\
\text { 3.54-4.43 km }\end{array}$ & 20.14 & 19.58 & 18.98 \\
\hline $\begin{array}{l}\text { Garmisch, 1 Apr, 14:00 } \\
\text { 4.91-5.81 km }\end{array}$ & 17.93 & 16.76 & 15.39 \\
\hline
\end{tabular}



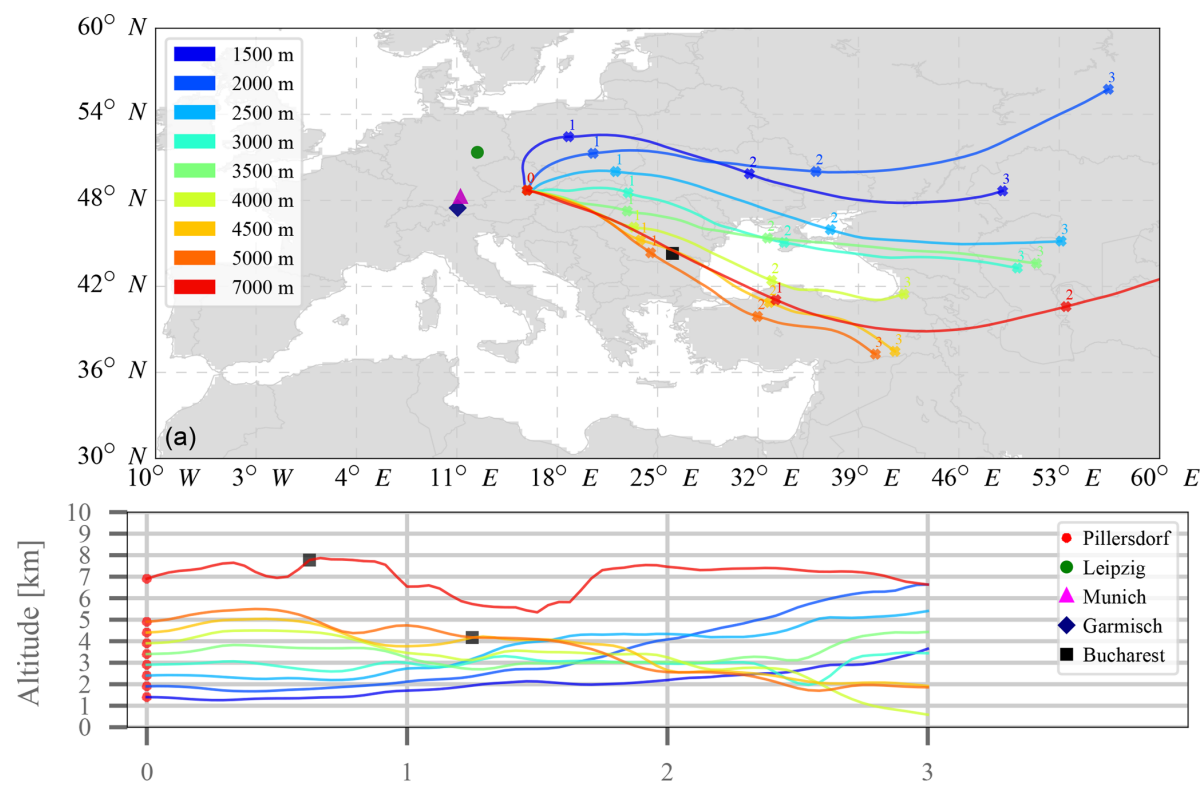
(b)
Days forward

Figure 6. Pattern of forward trajectories (a) and their altitude profile, including overpassed lidar stations (b) for Pillersdorf, 2 April 2014, 06:00.

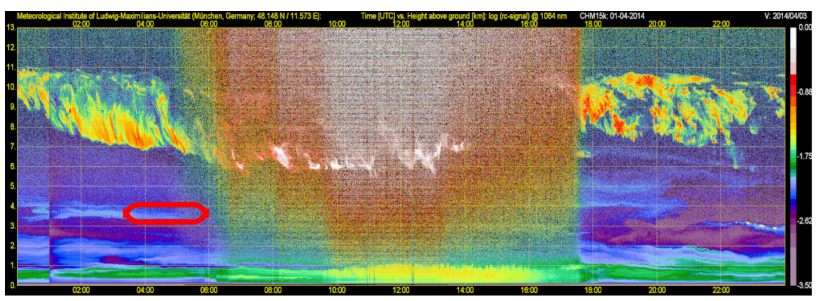

(a) Munich, 01 April 2014 ceilometer YALIS

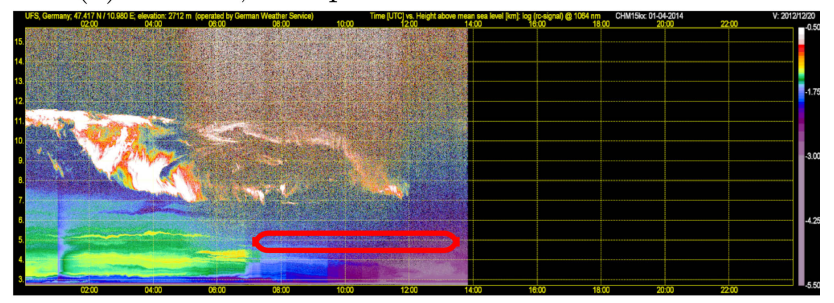

(b) Garmisch, 01 April 2014 ceilometer

Figure 7. Logarithm of the range-corrected signal at $1064 \mathrm{~nm}, 24 \mathrm{~h}$, for the Munich (a) and Garmisch (b) stations. The red boxes represent the identified layers.

The peak on 4 April was also analyzed similarly to the peak on 2 April. The corresponding vertical profiles of sulfate, dust, and total aerosol concentrations are shown in Fig. 13. From the backward- and forward-trajectory analyses, only one lidar station could be associated with a trajectory, for layer L2 at Pillersdorf at 12:00. The corresponding RCS at the lidar station is shown in Fig. 14. The SRS for the identified layers at Pillersdorf, 12:00, are presented in Fig. 15.

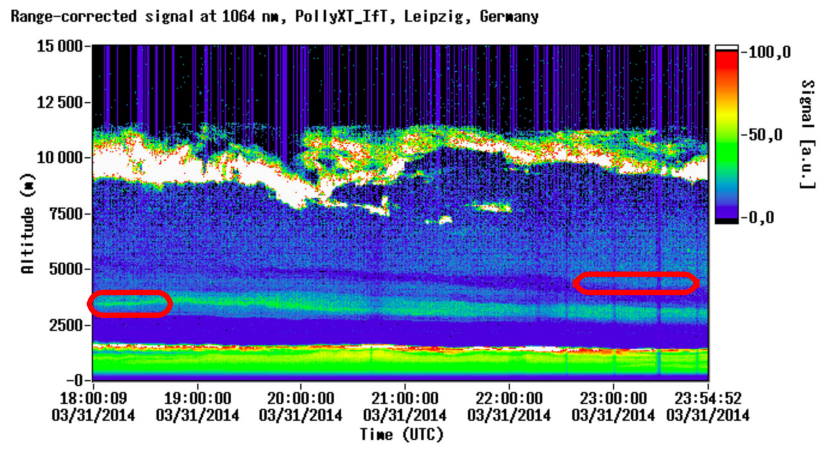

(a) Leipzig, 31 March 2014 PollyXT

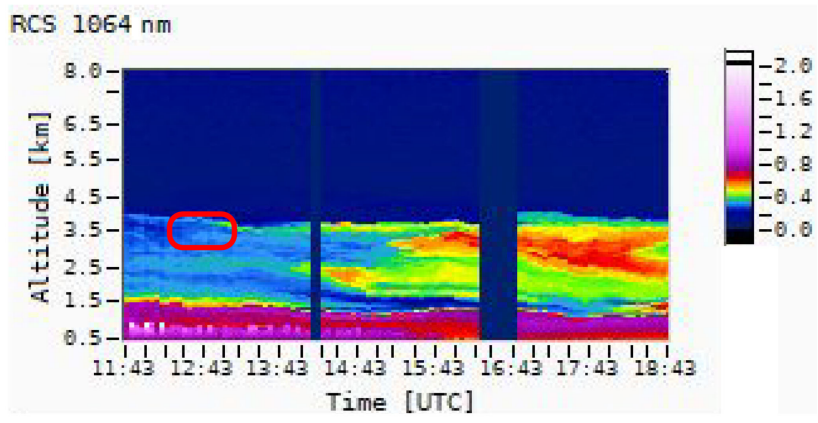

(b) Bucharest, 03 April 2014 RALI

Figure 8. Range-corrected signal at $1064 \mathrm{~nm}$ for the Leipzig (a) and Bucharest (b) stations. The red boxes represent the identified layers. 


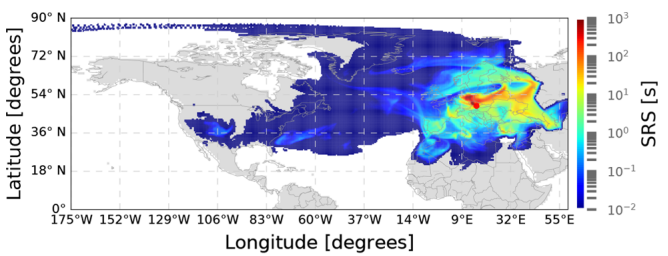

(a) Layer L1

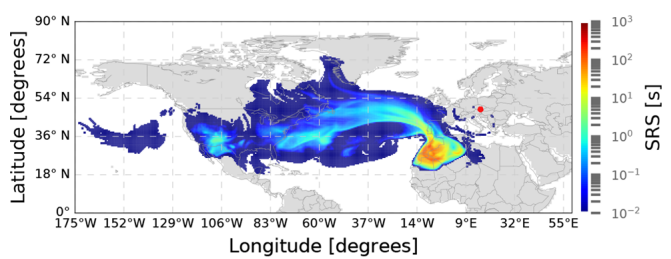

(c) Layer L3

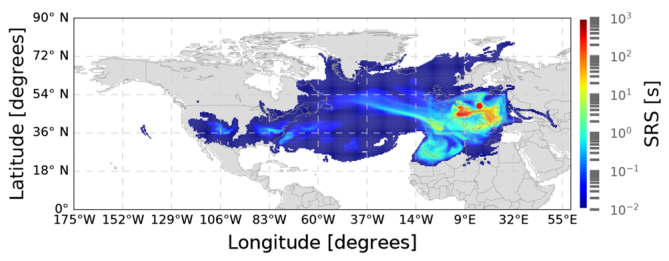

(b) Layer L2

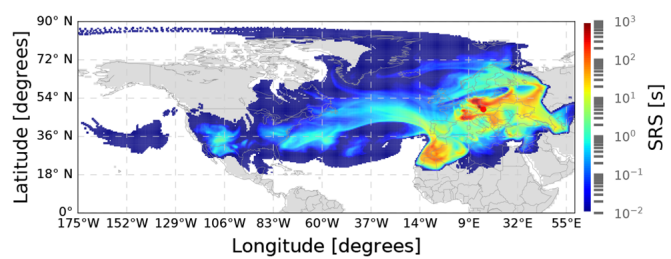

(d) Total column

Figure 9. Source-receptor sensitivity for layers L1 (a), L2 (b), and L3 (c) and total column (d), Pillersdorf, 2 April, 06:00.

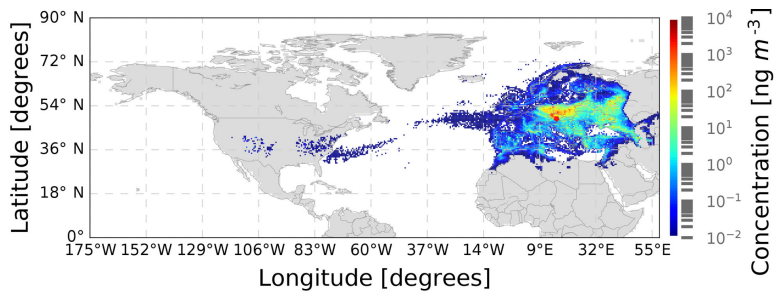

(a) Pillersdorf, 02 April, 06:00, layer L1

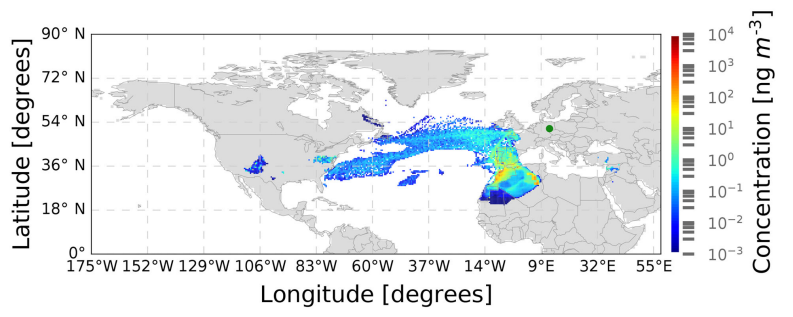

(b) Leipzig, 31 March, 18:00, layer corresponding to L1

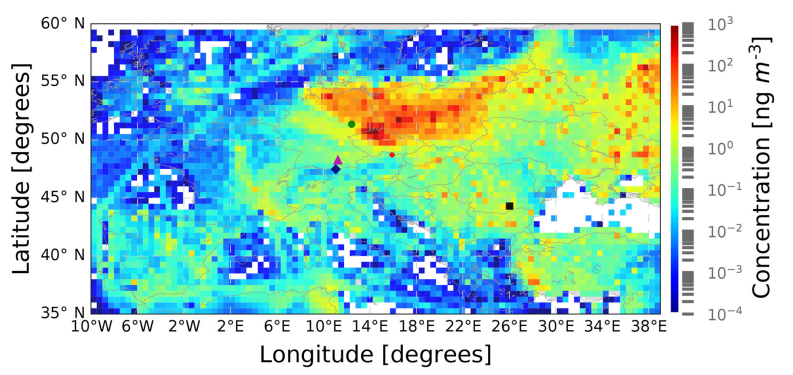

(c) Pillersdorf, 02 April, 06:00, layer L1, zoomed

Figure 10. Relative distributions of $\mathrm{SO}_{2}$ sources for Pillersdorf layer L1 (a), Leipzig (b); zoomed distribution for Pillersdorf layer L1 (c).

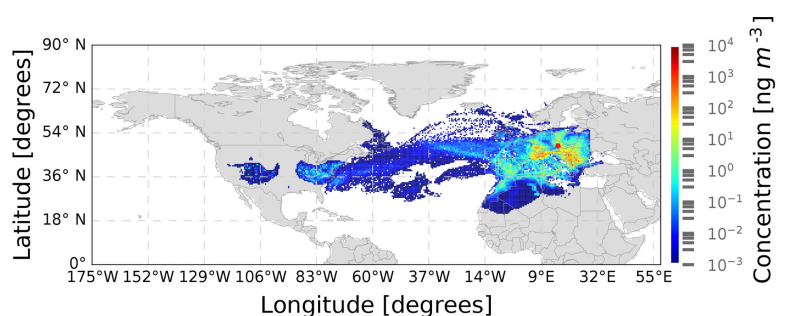

(a) Pillersdorf, 02 April, 06:00, layer L2

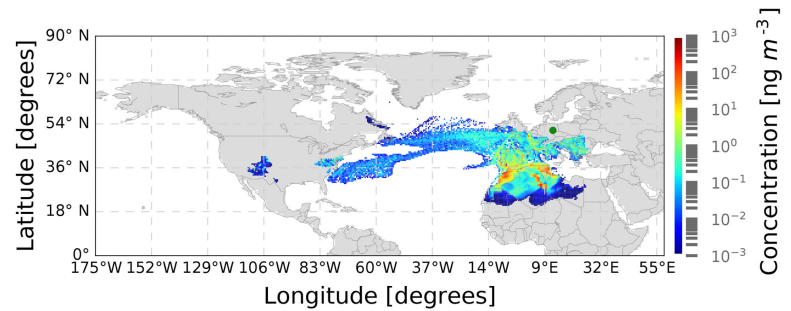

(b) Leipzig, 31 March, 23:00, layer corresponding to L2

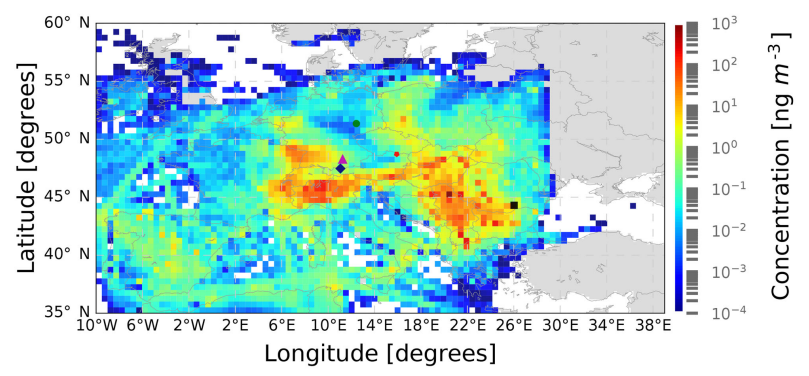

(c) Pillersdorf, 02 April, 06:00, layer L2, zoomed

Figure 11. Relative distributions of $\mathrm{SO}_{2}$ sources for Pillersdorf layer L2 (a), Leipzig (b); zoomed distribution for Pillersdorf layer L2 (c). 


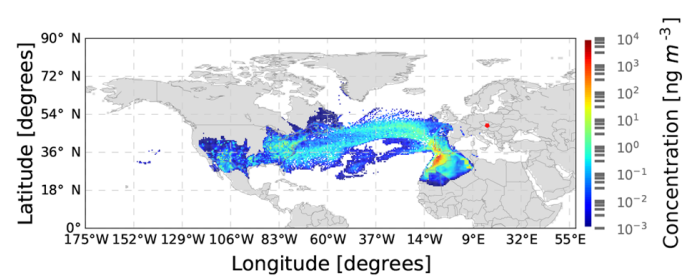

(a) Pillersdorf, 02 April, 06:00, layer L3

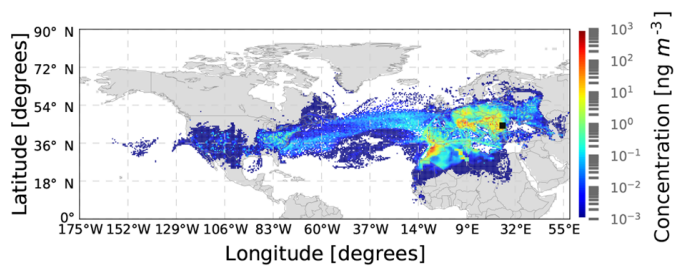

(c) Bucharest, 03 April, 13:00, layer corresponding to L3

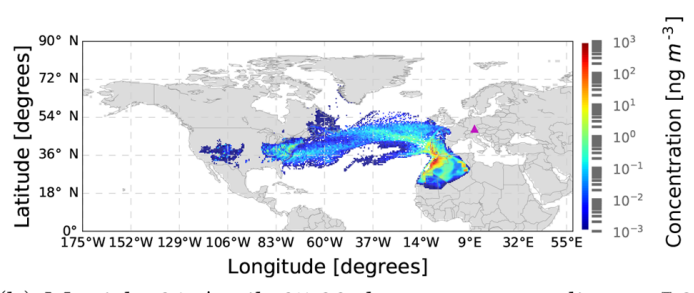

(b) Munich, 01 April, 05:00, layer corresponding to L3

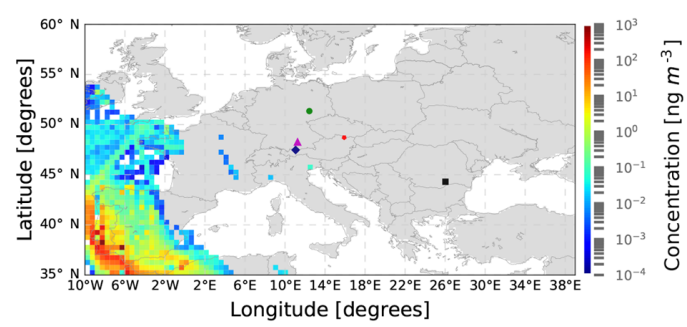

(d) Pillersdorf, 02 April, 06:00, layer L3, zoomed

Figure 12. Relative distributions of $\mathrm{SO}_{2}$ sources for Pillersdorf layer L3 (a), Munich (b), and Bucharest (c); zoomed distribution for Pillersdorf layer L3 (d).

Table 3. Optical properties, sulfate fraction, and aerosol types for aerosol layers corresponding to Pillersdorf, 2 April 2014, 06:00.

\begin{tabular}{|c|c|c|c|c|c|}
\hline Layer & $\begin{array}{l}\text { LR } \\
\text { (sr) }\end{array}$ & PDepR & $\mathrm{AE}$ & SF & Type \\
\hline $\begin{array}{c}\text { Pillersdorf } \\
2 \mathrm{Apr}, 06: 00 \\
0.55-1.50 \mathrm{~km}\end{array}$ & 51 & 0.22 & 0.67 & 0.49 & Polluted dust \\
\hline $\begin{array}{c}\text { Pillersdorf } \\
2 \mathrm{Apr}, 06: 00 \\
1.98-3.11 \mathrm{~km}\end{array}$ & 55 & 0.10 & 0.76 & 0.33 & Mixed dust \\
\hline $\begin{array}{c}\text { Pillersdorf } \\
2 \mathrm{Apr}, 06: 00 \\
4.20-6.15 \mathrm{~km}\end{array}$ & 54 & 0.07 & 0.74 & 0.62 & Mixed dust \\
\hline $\begin{array}{c}\text { Leipzig } \\
\text { 31 Mar, 18:00 } \\
2.70-3.75 \mathrm{~km}\end{array}$ & 55 & 0.20 & 0.79 & 0.25 & Polluted dust \\
\hline $\begin{array}{c}\text { Leipzig } \\
\text { 31 Mar, 23:00 } \\
\text { 3.85-4.20 km }\end{array}$ & 54 & 0.17 & 0.79 & 0.44 & Mixed dust \\
\hline $\begin{array}{c}\text { Bucharest } \\
3 \mathrm{Apr}, 13: 00 \\
2.70-4.05 \mathrm{~km}\end{array}$ & 54 & 0.14 & 0.71 & 0.55 & Mixed dust \\
\hline $\begin{array}{c}\text { Munich } \\
1 \mathrm{Apr}, 05: 00 \\
3.54-4.43 \mathrm{~km}\end{array}$ & 47 & 0.18 & 0.75 & 0.40 & Mixed dust \\
\hline $\begin{array}{c}\text { Garmisch } \\
1 \mathrm{Apr}, 14: 00 \\
4.91-5.81 \mathrm{~km}\end{array}$ & 45 & 0.16 & 0.71 & 0.41 & Mixed dust \\
\hline
\end{tabular}

Figure 13. CAMS aerosol, sulfate, and dust profiles for 4 April 2014, Pillersdorf. The gray area represents the identified sulfate layers. Altitudes are given in kilometers above ground level.

Layers at Pillersdorf were associated with layers at the lidar stations; they are given in Table 4. The comparison of the aerosol concentrations at the overpassed lidar station is given in Table 5, and the optical properties are given in Table 6.

\subsection{Discussion of the results}

The daily variations in the in situ measurements of $\mathrm{SO}_{2}, \mathrm{O}_{3}$, $\mathrm{PM}_{2.5}$, and $\mathrm{PM}_{10}$ concentrations depend on more factors, 


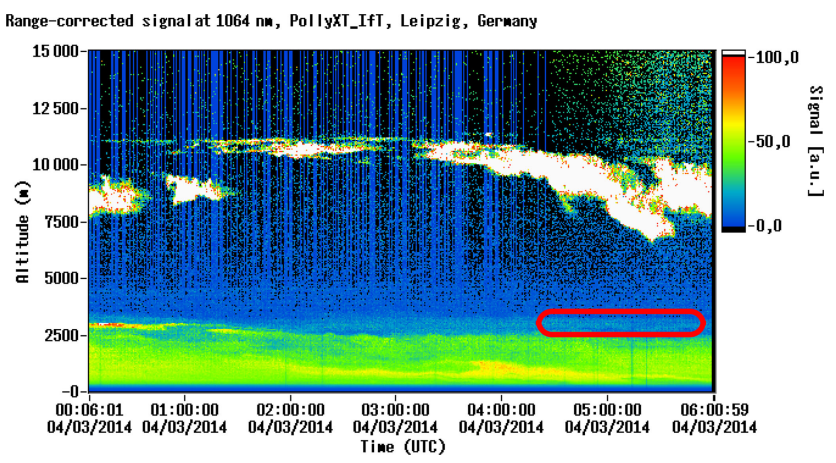

Figure 14. Range-corrected signal at $1064 \mathrm{~nm}$ for Leipzig station, 3 April 2014. The red box represents the identified layer.

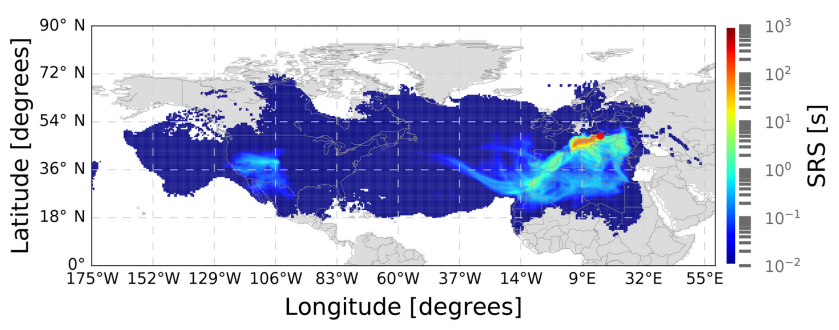

(a) Pillersdorf, 04 April, 12:00, layer L1

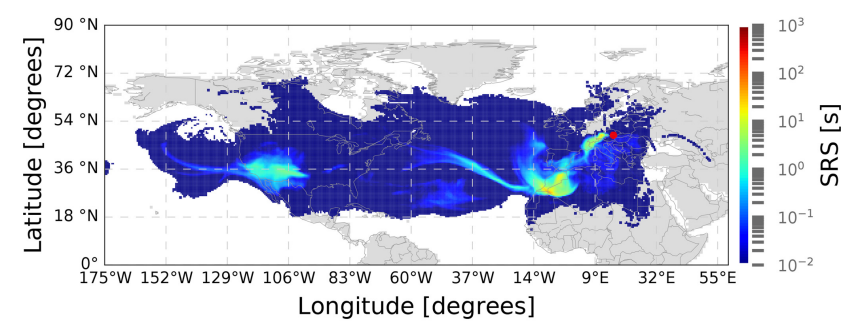

(b) Pillersdorf, 04 April, 12:00, layer L2

Figure 15. Source-receptor sensitivity for layers L1 (a) and L2 (b), Pillersdorf, 4 April, 12:00.

such as variations in source emissions, photochemical reactions, meteorological conditions, planetary boundary layer heights, and short-, medium-, and long-range transport of aerosols.

Figure 1 indicates a period between 27 March and 6 April in which in situ measurements of $\mathrm{SO}_{2}, \mathrm{O}_{3}, \mathrm{PM}_{2.5}$, and $\mathrm{PM}_{10}$ concentrations recorded at Pillersdorf exceed the averaged values for the period 15 March-14 April 2014. A significant load of aerosols in the atmosphere in this period is also confirmed by the AOD values between 0.07 and 0.73 for Pillersdorf, retrieved from CAMS products, which are above the AOD threshold of 0.06 for clear atmosphere (Kaskaoutis et al., 2012). For the period 27 to 31 March, no significant load of aerosols is observed at the lidar stations around Pillersdorf; therefore no medium- or long-range transport of aerosols is involved. The source-receptor sensitivity computed for 31 March (not shown) points to a short-range-
Table 4. Association of layers from lidar measurements with layers and trajectories computed for Pillersdorf, 4 April 2014, 12:00.

\begin{tabular}{llc}
\hline \multirow{2}{*}{ Pillersdorf } & \multicolumn{2}{c}{ Lidar station, time } \\
\cline { 2 - 2 } & Traj. alt. & Lidar layer \\
\hline L1: $1.98-4.50 \mathrm{~km}$ & Leipzig, 3 Apr, 05:00 \\
& $2.96 \mathrm{~km}$ & $2.70-3.45 \mathrm{~km}$ \\
\hline
\end{tabular}

Table 5. Comparison of sulfate concentration computed from lidar measurements, CAMS data and FLEXPART for layers at lidar stations associated with layers from Pillersdorf, 4 April 2014, 12:00.

\begin{tabular}{lrrr}
\hline Layer & $\begin{array}{r}C_{\text {lidar }} \\
\left(\mu \mathrm{g} \mathrm{m}^{-3}\right)\end{array}$ & $\begin{array}{r}C_{\text {cams }} \\
\left(\mu \mathrm{g} \mathrm{m}^{-3}\right)\end{array}$ & $\begin{array}{r}C_{\text {flexpart }} \\
\left(\mu \mathrm{g} \mathrm{m}^{-3}\right)\end{array}$ \\
\hline $\begin{array}{l}\text { Leipzig, 3 Apr, 12:00 } \\
\text { 2.70-3.45 km }\end{array}$ & 8.38 & 6.75 & 7.99 \\
\hline
\end{tabular}

transported event, of small duration and at low altitude, with sources in the southeast of Austria. This event is not described in this paper.

From a qualitative analysis of in situ concentrations for $\mathrm{PM}_{10}, \mathrm{PM}_{2.5}$, and $\mathrm{SO}_{2}$ (Fig. 1) and the CAMS time series of mixing ratios for dust, sulfate, and total aerosol at Pillersdorf (Fig. 2) and the lidar stations around Pillersdorf (Fig. 3), the presence of an event of sulfate transport over Europe can be inferred, with two peaks, on 2 and 4 April.

On 2 April, one observes from the concentration profiles (Fig. 4) that in the morning the dust was dominant in the layer between 0.55 and $1.50 \mathrm{~km}$ and in the layer between 1.98 and $3.11 \mathrm{~km}$, while sulfate was dominant in the higher-altitude layer, between 4.20 and $6.15 \mathrm{~km}$. In the afternoon, the sulfate concentration increased gradually in the lower layers, mixing with the dust, while the upper layer became thinner (layer range from 4.0 to $5.0 \mathrm{~km}$ ).

The back trajectories for 2 April (Fig. 5) show a consistent pattern. In the morning (00:00 and 06:00), the lower trajectories (below $2000 \mathrm{~m}$ ) originate from the eastern and southern United States (US), traverse the North Atlantic Ocean, and pass over central Europe, spending $\sim 6 \mathrm{~d}$ in this region, arriving at Pillersdorf from the northwest direction. The middlealtitude trajectories $(2000-5000 \mathrm{~m})$ originate from the southern US, traverse the ocean, and pass over northwest Africa (spending $\sim 3 \mathrm{~d}$ in the region), arriving in the central Europe from the southwest, then arriving along the Alps at Pillersdorf. The high-altitude trajectories (above $5000 \mathrm{~m}$ ) traverse the ocean, arriving at Pillersdorf from the west. In the afternoon (12:00 and 18:00), the lower trajectories originate from eastern Europe, while the middle-altitude and high-altitude trajectories originate from the eastern US, traverse the ocean and northwest Africa, and arriving at Pillersdorf from the west. 
Table 6. Optical properties, sulfate fraction, and aerosol types for aerosol layers corresponding to Pillersdorf, 4 April 2014, 12:00.

\begin{tabular}{lccccl}
\hline Layer & $\begin{array}{l}\text { LR } \\
(\mathrm{sr})\end{array}$ & PDepR & AE & SF & Type \\
\hline $\begin{array}{l}\text { Pillersdorf } \\
\text { 4 Apr, 12:00 } \\
\text { 0.55-1.50 km }\end{array}$ & 54 & 0.07 & 0.75 & 0.25 & Mixed dust \\
\hline $\begin{array}{l}\text { Pillersdorf } \\
\text { 4 Apr, 12:00 }\end{array}$ & 54 & 0.07 & 0.74 & 0.33 & Mixed dust \\
$\begin{array}{l}\text { 1.98-4.50 km } \\
\text { Leipzig }\end{array}$ & & & & & \\
$\begin{array}{l}\text { 3 Apr, 05:00 } \\
\text { 2.70-3.45 km }\end{array}$ & 55 & 0.11 & 0.76 & 0.74 & Mixed dust \\
\hline
\end{tabular}

The SRS patterns, shown in Fig. 9, and the relative distributions of $\mathrm{SO}_{2}$, shown in Figs. 10, 11, and 12, indicate the influence of five source regions for the transport of the sulfate event recorded on 2 April at Pillersdorf: the southern and eastern US, northwest Africa, central Europe, and eastern Europe.

For the lower layers, central Europe, including industrial centers from the "Black Triangle" (eastern Germany, southwest Poland, and Czech Republic), was the main source contributing to sulfate transported over northern Austria, where the Pillersdorf station is situated. Medium to smaller contributions come from sources in eastern Europe, northwest Africa, and the eastern US.

For the middle-altitude layers, sources from central Europe (northern Italy, Serbia, Hungary) contribute with similar emissions. Northwest Africa and the eastern US also have important contributions.

For the high-altitude layers, the main contributions come from northwest Africa, but sources from the southern and eastern US also contribute significantly. No contributions from Europe are seen for these layers.

For the peak on 4 April, having only one lidar station associated with aerosol trajectories, the analysis is more difficult. From the existing information, we can conclude that the pattern is similar to layers L2 and L3 from 2 April, with contributions from northern Italy, northwest Africa, and the southern US.

The AEs for the event have values between 0.67 and 0.79 , which correspond to a mixture of fine and coarse particles, with size distribution centered on $0.75 \mu \mathrm{m}$. For this size distribution, the sulfate (Ding et al., 2017) and the dust (accumulation mode) are the dominant aerosols. The LR is comparable for all sites, having values between 45 and $55 \mathrm{sr}$, while the linear PDepR has values between 0.07 and 0.22. These values correspond to low- to medium-absorbing aerosol with a nonspherical shape (Nicolae et al., 2018).

The aerosol type is determined from the optical properties for the layers identified in this event, at the in situ station and the lidar stations. A consistent aerosol type was found between the in situ station and the lidar stations along the trajectories. The changes in the values of the aerosol LR, AE, and linear PDepR along the trajectories can be explained by

- the mixing of dust with secondary sulfate from anthropogenic sources during the transport paths to Leipzig, Munich, Garmisch-Partenkirchen, Pillersdorf, and Bucharest and

- the adsorption of the $\mathrm{SO}_{2}$ on oxides contained in the mineral dust. The sulfate particles are expected to be formed by $\mathrm{SO}_{2}$ oxidizing on dust surface due to mineral oxide compounds from dust (e.g., hematite).

\section{Conclusions}

The excess of $\mathrm{SO}_{2}, \mathrm{PM}_{2.5}, \mathrm{PM}_{10}$, and $\mathrm{O}_{3}$ observed in the period 1-6 April 2014 at the Austrian air quality background station Pillersdorf was analyzed using in situ data, lidar measurements at the closest EARLINET stations around the in situ site, CAMS near-real-time data, and aerosol and atmospheric transport modeling. This excess was associated with the transport of sulfate aerosols, mixed during the transport with dust. By correlating the local information with a trajectory analysis and an analysis of aerosol potential sources, a complex pattern of contributions to sulfate at the in situ station was found. The lower layers (below $2000 \mathrm{~m}$ ) originated mainly from central Europe. Medium to smaller contributions came from sources in eastern Europe, northwest Africa, and the eastern US. For the middle-altitude layers (between 2000 and $5000 \mathrm{~m}$ ), sources from central Europe (northern Italy, Serbia, Hungary) contributed with similar emissions. Northwest Africa and the eastern US also have important contributions. The high-altitude layers (above $5000 \mathrm{~m}$ ) originated from sources from northwest Africa and from the southern and eastern US, as transported secondary sulfate mixed with dust. The effect of medium- and longrange transport of aerosol is significant, and can not be neglected when analyzing the air quality at an in situ station. For a quantitative analysis and modeling of aerosol deposition, more measurements are needed, including precise vertical aerosol profiles at the in situ station.

The spring period studied in this paper is characterized by low, if any, deep convection. For the summer period, one expects, however, to have strong convective activity over central Europe. A study of the summer periods for the years 2014-2017 for the same region was also performed; the results will be presented in a separate paper.

The methodology developed in this paper allows us to obtain a better understanding of the effects of aerosol transport on the in situ measurements. It can be used as a general tool to correlate measurements at in situ stations with groundbased remote-sensing stations located around these in situ stations. A dedicated paper for the methodology, extended 
to trace gases and other aerosols, with analysis of more case studies is under preparation.

Data availability. The lidar and the ceilometer data used in this study are available publicly upon registration at http://data.earlinet. org (last access: 9 May 2019); details for registrations are available at https://www.earlinet.org (last access: 9 May 2019). The in situ data for Austria EMEP stations are publicly available at http://www.umweltbundesamt.at/umweltsituation/luft/luftguete_ aktuell/monatsberichte/mb2014/. The MACCity inventory database from ECCAD is publicly available upon registration at https:// eccad3.sedoo.fr/ (last access: 9 May 2019). The CAMS NRT data are publicly available upon registration at https://apps.ecmwf.int/ datasets/data/cams-nrealtime. The meteorological data used as input in the FLEXPART model are retrieved from the ECMWF Meteorological Archival and Retrieval System (MARS), following the instructions described at https://confluence.ecmwf.int//display/ UDOC/MARS+user+documentation (last access: 9 May 2019).

Supplement. The supplement related to this article is available online at: https://doi.org/10.5194/acp-19-6235-2019-supplement.

Author contributions. CT collected and processed all data, developed the methodology, and performed the data analysis. Both authors contributed to the optimization of the analysis and the interpretation of the results. PS provided the pre-release of FLEXPART version 10 , with a better wet deposition and other improvements. The paper was prepared by CT with contributions from PS.

Competing interests. The authors declare that they have no conflict of interest.

Special issue statement. This article is part of the special issue "EARLINET aerosol profiling: contributions to atmospheric and climate research". It is not associated with a conference.

Acknowledgements. We thank the principal investigators and their staff for establishing and maintaining the EARLINET lidar sites, the DWD ceilometers, and the AERONET stations. We thank the staff from the Environment Agency Austria, who provided the in situ data. We acknowledge ECCAD and CAMS for making data accessible and providing tools for data analysis.

Financial support. This research has been supported by the Austrian Science Fund (FWF): project number M-2031, MeitnerProgramm).

Review statement. This paper was edited by Eduardo Landulfo and reviewed by two anonymous referees.

\section{References}

AeroCom: AeroCom: Aerosol Comparisons between Observations and Models, available at: http://aerocom.met.no (last access: 7 May 2019), 2018.

Ansmann, A., Riebesell, M., Wandinger, U., Weitkamp, C., Voss, E., Lahmann, W., and Michaelis, W.: Combined raman elasticbackscatter LIDAR for vertical profiling of moisture, aerosol extinction, backscatter, and LIDAR ratio, Appl. Phys. B, 55, 18-28, https://doi.org/10.1007/BF00348608, 1992.

Ansmann, A., Baars, H., Chudnovsky, A., Mattis, I., Veselovskii, I., Haarig, M., Seifert, P., Engelmann, R., and Wandinger, U.: Extreme levels of Canadian wildfire smoke in the stratosphere over central Europe on 21-22 August 2017, Atmos. Chem. Phys., 18, 11831-11845, https://doi.org/10.5194/acp-18-118312018, 2018.

Belegante, L., Nicolae, D., Nemuc, A., Talianu, C., and Derognat, C.: Retrieval of the boundary layer height from active and passive remote sensors. Comparison with a NWP model, Acta Geophys., 62, 276-289, https://doi.org/10.2478/s11600-013-0167-4, 2014.

Benedetti, A., Morcrette, J.-J., Boucher, O., Dethof, A., Engelen, R. J., Fisher, M., Flentje, H., Huneeus, N., Jones, L., Kaiser, J. W., Kinne, S., Mangold, A., Razinger, M., Simmons, A. J., and Suttie, M.: Aerosol analysis and forecast in the European Centre for Medium-Range Weather Forecasts Integrated Forecast System: 2. Data assimilation, J. Geophys. Res., 114, D13205, https://doi.org/10.1029/2008JD011115, 2009.

Boesenberg, J., Matthias, V., Amodeo, A., Amoiridis, V., Ansmann, A., Baldasano, J. M., Balin, I., D., B., Böckmann, C., Boselli, A., Carlsson, G., Chaikovsky, A., Chourdakis, G., Comeron, A., Tomasi, F. D., Eixmann, R., Freudenthaler, V., Giehl, H., Grigorov, I., Hagard, A., Iarlori, M., Kirsche, A., Kolarov, G., Kolarev, L., Komguem, G., Kreipl, S., Kumpf, W., Larchevêque, G., Linné, H., Matthey, R., Mattis, I., Mekler, A., Mironova, I., Mitev, V., Mona, L., Müller, D., Music, S., Nickovic, S., Pandolfi, M., Papayannis, A., Pappalardo, G., Pelon, J., Pérez, C., Perrone, R. M., Persson, R., Resendes, D. P., Rizi, V., Rocadenbosch, F., Rodrigues, J. A., Sauvage, L., Schneidenbach, L., Schumacher, R., Shcherbakov, V., Simeonov, V., Sobolewski, P., Spinelli, N., Stachlewska, I., Stoyanov, D., Trickl, T., Tsaknakis, G., Vaughan, G., Wandinger, U., Wang, X., Wiegner, M., Zavrtanik, M., and Zerefos, C.: EARLINET: A European Aerosol Research Lidar Network to Establish an Aerosol Climatology, Max-Planck-Institute Report, 348, 1-191, available at: http://www.mpimet.mpg.de/fileadmin/publikationen/Reports/ max_scirep_348.pdf (last access: 7 May 2019), 2003.

CAMS: Copernicus Atmosphere Monitoring Service, available at: http://atmosphere.copernicus.eu/ (last access: 7 May 2019), 2018.

Cazacu, M. M., Timofte, A., Talianu, C., Nicolae, D., Danila, M. N., Unga, F., Dimitriu, D. G., and Gurlui, S.: Grimsvotn Volcano: atmospheric volcanic ash cloud investigations, modelling-forecast and experimental environmental approach upon the Romanian area, J. Optoelectron. Adv. M., 14, 517-522, 2012.

Chalbot, M., Lianou, M., Vei, I., Kotronarou, A., and Kavouras, I. G.: Spatial attribution of sulfate and dust aerosol sources in an urban area using receptor modeling coupled with Lagrangian trajectories, Atmos. Pollut. Res., 4, 346-353, https://doi.org/10.5094/APR.2013.039, 2013. 
Darras, S., Granier, C., Liousse, C., Boulanger, D., Elguindi, N., and Le Vu, H.: THE ECCAD DATABASE, VERSION 2: Emissions of Atmospheric Compounds \& Compilation of Ancillary Data, IGAC New, pp. 19-22, available at: http://www.igacproject.org/ sites/default/files/2018-03/Issue_61_FebMar_2018.pdf (last access: 7 May 2019), database available at: http://eccad.aeris-data. fr/ (last access: 7 May 2019), 2018.

Déandreis, C., Balkanski, Y., Dufresne, J. L., and Cozic, A.: Radiative forcing estimates of sulfate aerosol in coupled climate-chemistry models with emphasis on the role of the temporal variability, Atmos. Chem. Phys., 12, 5583-5602, https://doi.org/10.5194/acp-12-5583-2012, 2012.

Dee, D. P., Uppala, S. M., Simmons, A. J., Berrisford, P., Poli, P., Kobayashi, S., Andrae, U., Balmaseda, M. A., Balsamo, G., Bauer, P., Bechtold, P., Beljaars, A. C. M., van de Berg, L., Bidlot, J., Bormann, N., Delsol, C., Dragani, R., Fuentes, M., Geer, A. J., Haimberger, L., Healy, S. B., Hersbach, H., Hólm, E. V., Isaksen, L., Kållberg, P., Köhler, M., Matricardi, M., McNally, A. P., Monge-Sanz, B. M., Morcrette, J.-J., Park, B.-K., Peubey, C., de Rosnay, P., Tavolato, C., Thépaut, J.-N., and Vitart, F.: The ERA-Interim reanalysis: configuration and performance of the data assimilation system, Q. J. Roy. Meteor. Soc., 137, 553-597, https://doi.org/10.1002/qj.828, 2011.

Ding, X., Kong, L., Du, C., Zhanzakova, A., Fu, H., Tang, X., Wang, L., Yang, X., Chen, J., and Cheng, T.: Characteristics of size-resolved atmospheric inorganic and carbonaceous aerosols in urban Shanghai, Atmos. Environ., 167, 625-641, https://doi.org/10.1016/j.atmosenv.2017.08.043, 2017.

Dupart, Y., King, S. M., Nekat, B., Nowak, A., Wiedensohler, A., Herrmann, H., David, G., Thomas, B., Miffre, A., Rairoux, P., D'Anna, B., and George, C.: Mineral dust photochemistry induces nucleation events in the presence of $\mathrm{SO}_{2}$, P. Natl. Acad. Sci. USA, 109, 20842-20847, https://doi.org/10.1073/pnas.1212297109, 2012.

Eckhardt, S., Prata, A. J., Seibert, P., Stebel, K., and Stohl, A.: Estimation of the vertical profile of sulfur dioxide injection into the atmosphere by a volcanic eruption using satellite column measurements and inverse transport modeling, Atmos. Chem. Phys., 8, 3881-3897, https://doi.org/10.5194/acp-8-3881-2008, 2008.

Eckhardt, S., Cassiani, M., Evangeliou, N., Sollum, E., Pisso, I., and Stohl, A.: Source-receptor matrix calculation for deposited mass with the Lagrangian particle dispersion model FLEXPART v10.2 in backward mode, Geosci. Model Dev., 10, 4605-4618, https://doi.org/10.5194/gmd-10-4605-2017, 2017.

Engelmann, R., Kanitz, T., Baars, H., Heese, B., Althausen, D., Skupin, A., Wandinger, U., Komppula, M., Stachlewska, I. S., Amiridis, V., Marinou, E., Mattis, I., Linné, H., and Ansmann, A.: The automated multiwavelength Raman polarization and water-vapor lidar PollyXT: the neXT generation, Atmos. Meas. Tech., 9, 1767-1784, https://doi.org/10.5194/amt-9-1767-2016, 2016.

Fernald, F. G.: Analysis of atmospheric lidar observations: some comments, Appl. Optics, 23, 652, https://doi.org/10.1364/AO.23.000652, 1984.

FLEXTRA: FLEXTRA trajectory model, available at: https://www. flexpart.eu/wiki/FtAbout (last access: 7 May 2019), 2018.

Freudenthaler, V.: About the effects of polarising optics on lidar signals and the $\Delta 90$ calibration, Atmos. Meas. Tech., 9, 41814255, https://doi.org/10.5194/amt-9-4181-2016, 2016.
Kaskaoutis, D. G., Nastos, P. T., Kosmopoulos, P. G., and Kambezidis, H. D.: Characterising the long-range transport mechanisms of different aerosol types over Athens, Greece during 2000-2005, Int. J. Climatol., 32, 1249-1270, https://doi.org/10.1002/joc.2357, 2012.

Klett, J. D.: Stable analytical inversion solution for processing lidar returns., Appl. Optics, 20, 211-20, https://doi.org/10.1364/AO.20.000211, 1981.

Koepke, P., Hess, M., Schult, I., and Shettle, E. P.: Global Aerosol Data Set, Tech. rep., Max Plank Institute for Meteorology, Munich, ISSN 0937-1060, available at: http://www.mpimet.mpg.de/ fileadmin/publikationen/Reports/MPI-Report_243.pdf (last access: 7 May 2019), 1997.

Mamouri, R.-E. and Ansmann, A.: Potential of polarization/Raman lidar to separate fine dust, coarse dust, maritime, and anthropogenic aerosol profiles, Atmos. Meas. Tech., 10, 3403-3427, https://doi.org/10.5194/amt-10-3403-2017, 2017.

Mishchenko, M. I., Travis, L. D., and Mackowski, D. W.: Tmatrix computations of light scattering by nonspherical particles: A review, J. Quant. Spectrosc. Ra., 55, 535-575, https://doi.org/10.1016/0022-4073(96)00002-7, 1996.

Nicolae, D., Nemuc, A., Müller, D., Talianu, C., Vasilescu, J., Belegante, L., and Kolgotin, A.: Characterization of fresh and aged biomass burning events using multiwavelength Raman lidar and mass spectrometry, J. Geophys. Res.-Atmos., 118, 2956-2965, https://doi.org/10.1002/jgrd.50324, 2013.

Nicolae, D., Vasilescu, J., Talianu, C., Binietoglou, I., Nicolae, V., Andrei, S., and Antonescu, B.: A neural network aerosol-typing algorithm based on lidar data, Atmos. Chem. Phys., 18, 1451114537, https://doi.org/10.5194/acp-18-14511-2018, 2018.

Papayannis, A., Nicolae, D., Kokkalis, P., Binietoglou, I., Talianu, C., Belegante, L., Tsaknakis, G., Cazacu, M., Vetres, I., and Ilic, L.: Optical, size and mass properties of mixed type aerosols in Greece and Romania as observed by synergy of lidar and sunphotometers in combination with model simulations: A case study, Sci. Total Environ., 500-501, 277-294, https://doi.org/10.1016/j.scitotenv.2014.08.101, 2014.

Pisso, I., Sollum, E., Grythe, H., Kristiansen, N., Cassiani, M., Eckhardt, S., Arnold, D., Morton, D., Thompson, R. L., Groot Zwaaftink, C. D., Evangeliou, N., Sodemann, H., Haimberger, L., Henne, S., Brunner, D., Burkhart, J. F., Fouilloux, A., Brioude, J., Philipp, A., Seibert, P., and Stohl, A.: The Lagrangian particle dispersion model FLEXPART version 10.3, Geosci. Model Dev. Discuss., https://doi.org/10.5194/gmd-2018333, in review, 2019.

Sauvage, B., Fontaine, A., Eckhardt, S., Auby, A., Boulanger, D., Petetin, H., Paugam, R., Athier, G., Cousin, J.-M., Darras, S., Nédélec, P., Stohl, A., Turquety, S., Cammas, J.-P., and Thouret, V.: Source attribution using FLEXPART and carbon monoxide emission inventories: SOFT-IO version 1.0, Atmos. Chem. Phys., 17, 15271-15292, https://doi.org/10.5194/acp-17-152712017, 2017.

Seibert, P. and Frank, A.: Source-receptor matrix calculation with a Lagrangian particle dispersion model in backward mode, Atmos. Chem. Phys., 4, 51-63, https://doi.org/10.5194/acp-4-512004, 2004.

Seinfeld, J. H. and Pandis, S. N.: Atmospheric Chemistry and Physics: From Air Pollution to Climate Change, A Wiley-Interscience publication, Wiley, available at: 
https://books.google.at/books?id=tZEpAQAAMAAJ (last access: 7 May 2019), 2006.

Solomon, S., Qin, D., Manning, M., Chen, Z., and Marquis, M. K. A.: Contribution of Working Group I to the Fourth Assessment Report of the Intergovernmental Panel on Climate Change, Cambridge University Press, Cambridge, United Kingdom and New York, NY, USA, available at: http://www.ipcc. ch/publications_and_data/ar4/wg1/en/contents.html (last access: 7 May 2019), 2007.

Stocker, T. F., Qin, D., Plattner, G.-K., Tignor, M., Allen, S. K., Boschung, J., Nauels, A., Xia, Y., Bex, V., and Midgley, P. M.: IPCC, 2013: Climate Change 2013: The Physical Science Basis. Contribution of Working Group I to the Fifth Assessment Report of the Intergovernmental Panel on Climate Change, Cambridge University Press, Cambridge, United Kingdom and New York, NY, USA, available at: http://www.climatechange2013. org/report/full-report/ (last access: 7 May 2019), 2013.

Stohl, A., Wotawa, G., Seibert, P., and Kromp-Kolb, H.: Interpolation Errors in Wind Fields as a Function of Spatial and Temporal Resolution and Their Impact on Different Types of Kinematic Trajectories, J. Appl. Meteorol., 34, 2149-2165, https://doi.org/10.1175/15200450(1995)034<2149:IEIWFA>2.0.CO;2, 1995.

Stohl, A., Hittenberger, M., and Wotawa, G.: Validation of the lagrangian particle dispersion model FLEXPART against largescale tracer experiment data, Atmos. Environ., 32, 4245-4264, https://doi.org/10.1016/S1352-2310(98)00184-8, 1998.

Stohl, A., Forster, C., Frank, A., Seibert, P., and Wotawa, G.: Technical note: The Lagrangian particle dispersion model FLEXPART version 6.2, Atmos. Chem. Phys., 5, 2461-2474, https://doi.org/10.5194/acp-5-2461-2005, 2005.

Umweltbundesamt Austria: MONATSBERICHT HINTERGRUNDMESSNETZ UMWELTBUNDESAMT, Tech. rep., Umweltbundesamt Austria, available at: http://www.umweltbundesamt.at/umweltsituation/luft/luftguete_ aktuell/monatsberichte/mb2014/ (last access: 7 May 2019), 2014.
Wandinger, U., Freudenthaler, V., Baars, H., Amodeo, A., Engelmann, R., Mattis, I., Groß, S., Pappalardo, G., Giunta, A., D’Amico, G., Chaikovsky, A., Osipenko, F., Slesar, A., Nicolae, D., Belegante, L., Talianu, C., Serikov, I., Linné, H., Jansen, F., Apituley, A., Wilson, K. M., de Graaf, M., Trickl, T., Giehl, H., Adam, M., Comerón, A., Muñoz-Porcar, C., Rocadenbosch, F., Sicard, M., Tomás, S., Lange, D., Kumar, D., Pujadas, M., Molero, F., Fernández, A. J., Alados-Arboledas, L., Bravo-Aranda, J. A., Navas-Guzmán, F., Guerrero-Rascado, J. L., Granados-Muñoz, M. J., Preißler, J., Wagner, F., Gausa, M., Grigorov, I., Stoyanov, D., Iarlori, M., Rizi, V., Spinelli, N., Boselli, A., Wang, X., Lo Feudo, T., Perrone, M. R., De Tomasi, F., and Burlizzi, P.: EARLINET instrument intercomparison campaigns: overview on strategy and results, Atmos. Meas. Tech., 9, 1001-1023, https://doi.org/10.5194/amt-9-1001-2016, 2016.

Wiegner, M. and Geiß, A.: Aerosol profiling with the Jenoptik ceilometer CHM15kx, Atmos. Meas. Tech., 5, 1953-1964, https://doi.org/10.5194/amt-5-1953-2012, 2012.

Yang, Y., Wang, H., Smith, S. J., Easter, R., Ma, P.-L., Qian, Y., Yu, H., Li, C., and Rasch, P. J.: Global source attribution of sulfate concentration and direct and indirect radiative forcing, Atmos. Chem. Phys., 17, 8903-8922, https://doi.org/10.5194/acp17-8903-2017, 2017.

Zhang, Q., Jimenez, J. L., Canagaratna, M. R., Allan, J. D., Coe, H., Ulbrich, I., Alfarra, M. R., Takami, A., Middlebrook, A. M., Sun, Y. L., Dzepina, K., Dunlea, E., Docherty, K., DeCarlo, P. F., Salcedo, D., Onasch, T., Jayne, J. T., Miyoshi, T., Shimono, A., Hatakeyama, S., Takegawa, N., Kondo, Y., Schneider, J., Drewnick, F., Borrmann, S., Weimer, S., Demerjian, K., Williams, P., Bower, K., Bahreini, R., Cottrell, L., Griffin, R. J., Rautiainen, J., Sun, J. Y., Zhang, Y. M., and Worsnop, D. R.: Ubiquity and dominance of oxygenated species in organic aerosols in anthropogenically-influenced Northern Hemisphere midlatitudes, Geophys. Res. Lett., 34, L13801, https://doi.org/10.1029/2007GL029979, 2007. 